\title{
Understanding the key to targeting the IGF axis in cancer: a biomarker assessment
}

\author{
Kunal Amratlal Lodhia ${ }^{\dagger}$, Piyawan Tienchaiananda ${ }^{\dagger}$ and Paul Haluska* \\ Department of Oncology, Mayo Clinic, Rochester, MN, USA
}

Type 1 insulin like growth factor receptor (IGF-1R) targeted therapies showed compelling pre-clinical evidence; however, to date, this has failed to translate into patient benefit in Phase 2/3 trials in unselected patients. This was further complicated by the toxicity, including hyperglycemia, which largely results from the overlap between IGF and insulin

\section{OPEN ACCESS}

Edited by:

Antonino Belfiore,

University Magna Graecia of

Catanzaro, Italy

Reviewed by:

Ivan Casaburi,

University of Calabria, Italy

Ilan Bruchim,

Hillel Yaffe Medical Center, Israel Anna Blecher,

Hillel Yaffe Medical Center, Israel

(in collaboration with llan Bruchim)

*Correspondence:

Paul Haluska,

Department of Oncology, Mayo Clinic, 200 South First Street, Rochester,

MN 55905, USA

haluska.paul@mayo.edu

${ }^{\dagger}$ Kunal Amratlal Lodhia and

Piyawan Tienchaiananda have

contributed equally to this work.

Specialty section:

This article was submitted to Cancer Endocrinology, a section of the journal

Frontiers in Oncology

Received: 06 April 2015 Accepted: 08 June 2015

Published: 08 July 2015

Citation:

Lodhia KA, Tienchaiananda $P$ and Haluska $P$ (2015) Understanding the key to targeting the IGF axis in cancer: a biomarker assessment. Front. Oncol. 5:142.

doi: 10.3389/fonc.2015.00142 signaling systems and associated feedback mechanisms. This has halted the clinical development of inhibitors targeting IGF signaling, which has limited the availability of biopsy samples for correlative studies to understand biomarkers of response. Indeed, a major factor contributing to lack of clinical benefit of IGF targeting agents has been difficulty in identifying patients with tumors driven by IGF signaling due to the lack of predictive biomarkers. In this review, we will describe the IGF system, rationale for targeting IGF signaling, the potential liabilities of targeting strategies, and potential biomarkers that may improve success.

Keywords: insulin receptor, insulin-like growth factor receptor, IGF binding proteins, biomarker discovery, IGF system and signaling, insulin receptor substrate proteins, endocrine system diseases, targeted therapies

\section{Background}

The type 1 insulin-like growth factor receptor (IGF-1R) and its signaling components are required for the development of the malignant phenotype, and low IGF bioactivity protects against the development of clinical cancers (1). IGF-1R overexpression has been consistently shown in multiple types of cancer, including pediatric and epithelial cancer and sarcomas $(2,3)$. The first assessment of IGF-1R targeted treatment used $\alpha$ IR-3, a mouse monoclonal antibody (mAb), which blocked IGF-1 binding to IGF-1R and inhibited growth of estrogen-independent breast cancers in vitro and in vivo (4-6). This has made IGF-1R a very attractive target, and currently two main therapeutic approaches are being developed: anti-IGF-1R monoclonal blocking antibodies and small molecule tyrosine kinase inhibitors (TKIs) (7-9). IGF-1R antibodies function by blocking interactions between the ligand and receptor, subsequently leading to receptor internalization and degradation (10). Additionally, IGF-1R mAbs result in insulin receptor (INSR) downregulation in cells expressing IGF-1RIR hybrid receptors (HR) $(10,11)$. IGF-1R TKIs act by competing with ATP for binding in the kinase domain of IGF-1R and INSR, due to the highly conserved structure (7).

Eight IGF-1R targeting mAbs have been evaluated clinically, including AVE1642, BIIB022, cixutumumab, dalotuzumab, figitumumab, ganitumab, robatumumab, and R1507 (7). Clinical trials using these antibodies have shown limited activity in uncommon tumors such as ovarian carcinomas and Ewings sarcomas, as well as thymonal and adrenocortical carcinomas, but little benefit as single agent in common cancers. In addition, IGF-1R antibodies were recently reported to have single agent activity in recurrent ovarian cancer (12). However, in combination with other forms of therapy such 
as chemotherapy or other targets agents, they have shown some evidence of clinical benefit $(7,9,13)$. For example, the combination of IGF-1R antibody with chemotherapy has led to significant increase in response rates, with little added toxicity in non-small cell lung cancer (NSCLC) $(14,15)$. However, this approach failed to prolong survival in unselected patients, leading to premature discontinuation of Phase 3 trail (16).

Six small molecule inhibitors have been evaluated clinically: BMS-754807, Insm-18 (NDGA), XL-228, OSI-906 (linsitnib), AXL1717 (PPP), and KW-2450 (7). Small molecule inhibitors may offer several potential advantages over blocking antibodies. Inhibitors can be administered orally and have a shorter halflife than antibodies, in the order of hours rather than days (17). This property can be exploited to allow for dosing flexibility, which can be helpful in optimizing scheduling IGF-1R inhibition with other agents. Moreover, the small molecule inhibitors target the tyrosine kinase domain of the IGF-1R, which shares a high degree of homology with the insulin receptor kinase domain. This allows for not only targeting of IGF-1R but also the INSR isoform, insulin receptor A (INSR-A), which can mediate tumor growth. Initial clinical experience suggests that co-inhibition of the metabolic isoform of the INSR, insulin receptor B (INSR-B), is tolerable (18).

It is possible that a reason for lack of success in targeting the IGF pathway is the lack of absolute dependence on IGF signaling for tumor survival. Alternatively, it is more likely that we simply have not selected the correct pathways for clinical investigation. This would be supported by anecdotal evidence of antitumor activity. As such, the key issue for successful clinical use of IGF-1R inhibiting drugs is the need to identify biomarkers that predict sensitivity to IGF-1R inhibition, in order to better select patients that would benefit from single agent or combine IGF-1R inhibition effectively with chemotherapy, radiotherapy, or other targeted agents.

\section{Insulin Receptor and Insulin-Like Growth Factor System}

The IGF system includes three ligands (IGF-1, IGF-2, and insulin) and two homolog receptors, which are IGF-1R and INSR. Each of these receptors are heterodimeric proteins consisting of two extracellular $\alpha$ subunits and two transmembrane $\beta$ subunits (19). There are two splice variants of the INSR: INSR-A, which is missing a 12 amino-acid sequence from exon 11 , and the full length isoform, INSR-B (20). INSR-B is predominately expressed in insulin target tissue: liver, adipose tissue, and muscle $(21,22)$. INSR-A is expressed in embryo and fetal tissue; therefore, it is called "the fetal INSR isoform" (23-25). Both INSR isoforms have the same affinities with insulin; however, INSR-B primarily mediates metabolic effects (26), whereas INSR-A promotes cell growth, proliferation, and survival $(27,28)$. IGF-2 binding affinity to INSR-A is very high when compared with INSR-B. In addition, the affinity of IGF-1 to INSR-A is 10-fold higher than INSR-B $(24,29)$. Proinsulin, which has inactive metabolic function, was recently found to be able to stimulate INSR-A with the same affinity as insulin and induced similar biological effect (30). The role of proinsulin in malignancy is still under investigation. The major downstream cascades of IGF system are PI3K/AKT/mTOR and
Ras/Raf/MEK/ERK (Figure 1) (31-36). Activation of INSRs also contributes to the downregulation of PTEN, enhancing PI3K activation (37). The action of insulin on signal transductions through INSR-A is somewhat different from those elicited by IGF-2 in terms of regulating certain gene and intracellular mediators (38, 39 ). The mitogenic effect from IGF-2 binding to INSR-A (IGF2/INSR-A loop) is more pronounced than insulin (39). Moreover, INSRs have signaling crosstalk with $\beta$-catenin/Wnt pathway involved in proliferation and differentiation program (40).

INSRs are overexpressed in several malignancies including breast, colon, lung, ovary, and thyroid cancer $(24,41,42)$. Additionally, INSR-A is the predominant isoform expressed in a variety of tumors such as breast, colon, ovarian, endometrium, and lung cancer $(24,27,43-45)$. In ovarian cancer cell lines, INSR-A also preferentially expressed and mediated signaling in response to low dose insulin and IGF-2 (45). Moreover, activation of IGF-2/INSRA loop promotes invasion and metastasis in choriocarcinoma (46), while downregulating of INSRs reduces cell proliferation, angiogenesis, and metastasis in cancer cells both in vitro and in vivo $(27,47)$. In colorectal cancer, INSRs expression was found only in blood vessels at the peritumoral region, but not in normal tissue, suggesting INSRs may be involved in promoting angiogenesis (48). These data suggest that INSRs itself can promote cell transformation and tumor development, and that INSR-A is an important component of IGF signaling.

Insulin growth factor signaling may also have a crucial role in cancer stem cell survival. Work by Bendall and colleagues identified IGF-2 as having a direct role in the survival and selfrenewal ability of pluripotent human embryonic stem cells (49). IGF-2 has also been shown to promote stemness though INSRA in neural stem cells in presence of IGF-1R blockade $(50,51)$. Similar observations were made in thyroid cancer and hepatocellular carcinoma (HCC), where undifferentiated cancer cells preferentially expressed higher levels of INSR-A and produced higher levels of IGF-2 in order to activate the autocrine loop (41, 52). In addition to the presence of INSR-A, a decreased ratio of INSR-A:INSR-B was reported to be associated with thyroid cancer, colon cancer, and HCC cell line differentiation to a more typical epithelial phenotype (53-55). Collectively, IGF-2/INSRA autocrine loop has been considered as an important signaling pathway in cancer stem cell biology, and INSR-A:INSR-B ratio may be important in the pluripotent phenotype of cancer cells.

Recent nucleotide sequencing and gene expression analysis reported an increased INSR-A:INSR-B ratio in cancer tissue when compared with normal tissue in breast, colon, lung, endometrioid uterine, HCC, clear cell renal, and papillary cell renal carcinomas (56). Furthermore, the prevalence of high INSR-A:INSR-B ratio was found in $>93 \%$ brain tumors and acute myeloid leukemias (56). The finding of increased INSR-A:INSR-B ratio was confirmed by quantitative PCR in breast, NSCLC, prostatic, HCC, and seminoma (56-59). In these reports, INSR-A mRNA expression level was similar in both tumor and adjacent healthy tissue, while INSR-B mRNA expression level was significantly decreased in tumor when compared to healthy tissue $(44,56,57,59,60)$. Activation of the EGRF/ERK pathway was associated with increased INSR-A:INSR-B ratio in HCC (61). In addition to expression of INSRs, increased INSR-A:INSR-B ratio may contribute to the 


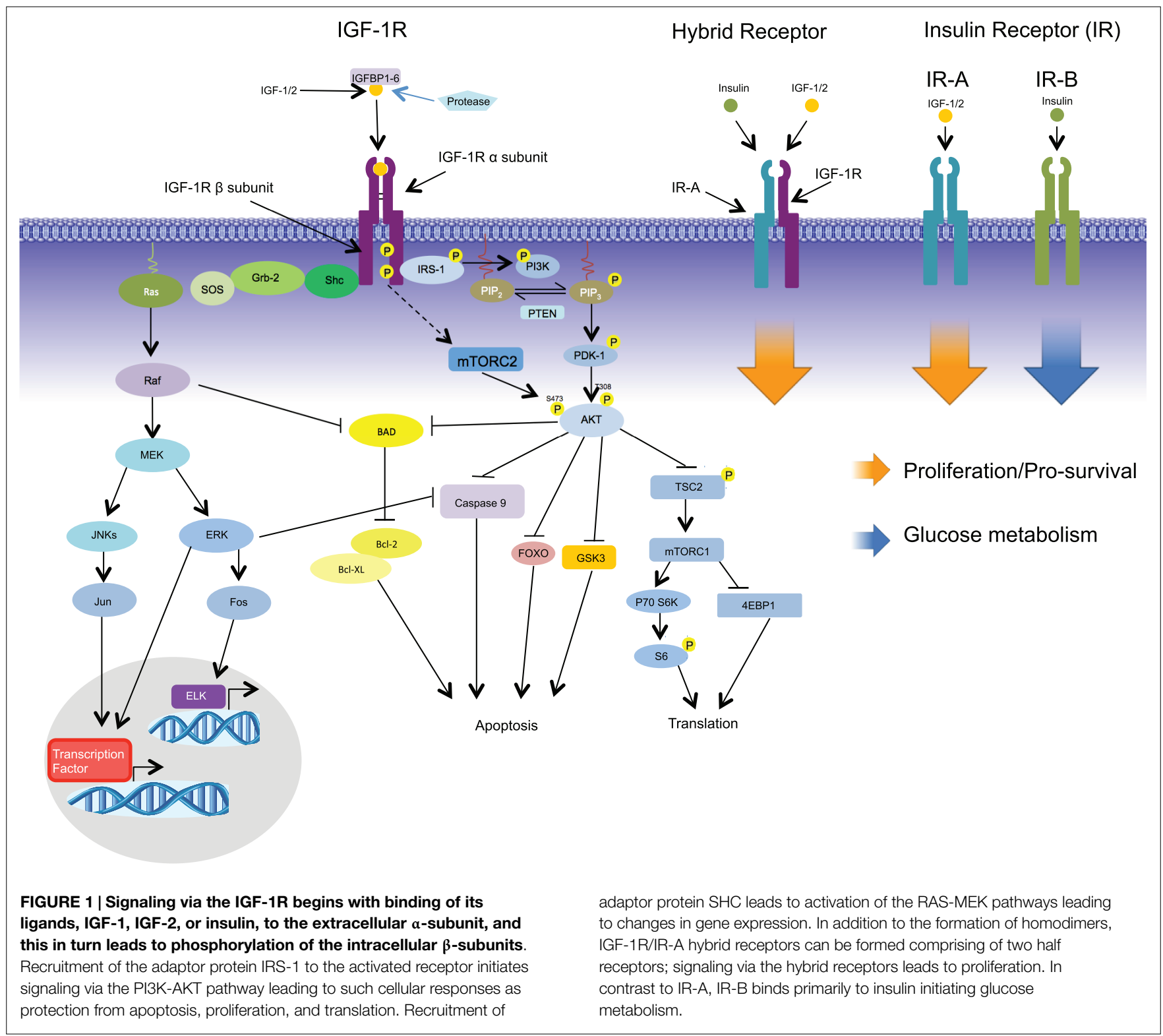

proliferation of various cancer types by both activation of IGF and EGFR pathway, raising the possibility of its value as a biomarker.

\section{Hybrid Receptors}

IGF-1R and INSRs share approximately $85 \%$ homology, with maximal homology in the kinase domain (62). Moreover, these two receptors can form HR A and B (HR-A and HR-B), depending on the respective associated INSR isoform $(63,64)$. This adds an additional level of complexity in understanding the signaling state of the IGF pathway. These HRs randomly assemble with the two INSR isoforms and IGF-1R with the same efficiency $(29,65-$ 68). Thus, a marked increased in INSR leads to the formation of HRs rather than IGF-1R homodimers. Both HR-A and HR$B$ have high affinities to IGF-1 and to a lesser extent for IGF$2(65,68)$. Cancer cells often express both IGF-1R and INSR-A that contribute to the activation of IGFs signaling by IGF-1 and to a lesser extent by IGF-2 $(42,66,69)$. The majority of breast cancer specimens expressed HRs rather than IGF-1R (66). In vitro experiments treating breast cancer cell lines overexpressing HRs with IGF-1 induced greater auto-phosphorylation compared to IGF-1R homodimers (66). Overexpression of INRSs and HRs was also shown on malignant prostate epithelial when compared to benign prostate epithelium and this was shown to correlate with a higher Gleason score associated with poorer prognosis (58).

\section{INSRs Signaling as a Resistant Mechanism to IGF-1R Inhibitory Agents}

Insulin receptor expression may lead to a compensatory mechanism for tumor treated with IGF-1R targets agents. In vitro work by Zhang and colleagues demonstrated that downreguation of the IGF-1R in breast cancer cell line leads to the increased insulin sensitivity (70). When IGF-1R was blocked, 
INSR-mediated ERK/AKT activity was increased in response to insulin at concentrations near to physiologic levels and enhanced INSR-A homodimer formation (71-73). In Ewing's sarcoma cell lines that acquired resistance to anti-IGF-1R mAbs and TKIs, overexpression of INSR-A homodimer and/or IGF-2 production was observed (74). Vincent and colleagues used a NSCLC model and colleagues demonstrated that dual inhibition of IGF-1R and INSRs more effectively reduced NSCLC cell proliferation in cells with high and low IGF-1R:INSR expression ratio (75). In this report, INSRs mediated NSCLC proliferation when only IGF-1R was blocked, suggesting that the resistant mechanisms to IGF$1 \mathrm{R}$ inhibitory agents may be the ability of tumor cell to switch from IGF-2/IGF-1R to IGF-2/INSR-A dependency (75). Moreover, IGF-1 might have a negative feedback at pituitary level causing growth hormone induced hyperinsulinemia consequently to INSR-A activation $(76,77)$. Altogether, INSRs play an important role in the mitogenic effect of IGFs signaling pathway and may contribute mechanisms of resistance to IGF inhibitory agents.

\section{INSR-A:INSR-B Ratio as a Cancer Biomarker}

In breast cancer, increased INSR-A:INSR-B ratio, measured by mRNA expression, has been reported in estrogen receptor positive $(\mathrm{ER}+)$ and negative (ER-) primary untreated breast tumors, and ER+ hormone refractory breast tumors (78). In addition, high INSR-A:INSR-B ratio was significantly higher in luminal $B$ than luminal A subtype. Increased INSR-A:INSR-B in breast cancer also correlated with high proliferation index by OncotypeDx and FAK activation $(44,60)$. Ratio of INSR-A:INSR-B may serve as a useful biomarker to predict prognosis in breast cancer. In contrast to breast cancer, in squamous cell lung carcinoma, high INSRA:INSR-B ratio was associated with lower epithelial-mesenchymal transition (EMT) gene signature and longer survival (56). A recent case control study of colorectal adenoma in patients found no difference in the total INSR mRNA; however, in patients with high plasma insulin, increased INSR-A:INSR-B ratio was associated with increased likelihood of having adenomas (79). Therefore, the usefulness of INSR-A:INSR-B ratio likely varies by tumor type and should be evaluated separately.

\section{INSRs and HRs as Cancer Biomarkers}

A high mRNA level of INSRs and phosphorylated INSRs is associated with poor prognostic features such as high-grade, advanced stage, and deep invasion in endometrial cancers (80). Furthermore, immunohistochemical staining of NSCLC, especially squamous cell carcinoma, demonstrated that overexpression of INSRs by immunohistochemistry (IHC) correlated with poor overall survival (OS) (81). In early stage or lymph node negative breast cancer, high expression of INSRs was associated with favorable progression free survival (PFS) and OS $(82,83)$. Contrary to a result from unspecified breast cancer patients, total INSRs and phosphorylated IGF-1R/INSRs overexpression by IHC was related to poor OS in all breast cancer subtypes including those with acquired resistance to tamoxifen (84). These inconclusive results of INSRs as potential prognosis biomarkers in breast cancer warrant the need for further studies.
Anti-IGF-1R mAbs have demonstrated potent growth inhibition in breast cancer cell lines with a low HR:IGF-1R ratio (66). Subsequent studies in breast cancer examining high HR:IGF$1 \mathrm{R}$ demonstrated greater anti-tumoral activity using h7C10, a $\mathrm{mAb}$ targeting $\mathrm{HR}$ and IGF-1R, compared to mAbs targeting IGF-1R alone (85). High ratio of INSR:IGF-1R also conveyed resistance to the IGF-1R mAb cixutumumab in breast cancer cell lines (86). Hence, for breast cancer, INSR/HR:IGF-1R ratio may predict response to $\mathrm{mAb}$ against IGF-1R. In vivo data from INSRs knockout pancreatic neuroendocrine tumor cell lines demonstrated that lack of INSR increased sensitivity to cixutumumab (86). However, this was not seen in gastric cancer and HCC cell lines. A study by Kim et al. demonstrated that high level of IGF-1R and INSRs expression predicted favorable sensitivity to IGF-1R inhibition by the mAb figitumumab (87). Furthermore, transfection of low INSR expressing cells with an INSR-expression construct resulted in increased formation of HRs and enhanced growth inhibition from figitumumab (87). Finally, in this report, high HR expression was a strong predictive biomarker for figitumumab efficacy (87). The role of INSR/HRs expression as potential predictive biomarker to $\mathrm{mAb}$ to IGF-1R is needed to be further evaluated because of conflicting results.

Small molecule TKIs offer an approach to target both IGF-1R and HR simultaneously. The dual IGF-1R/INSR small molecule inhibitor OSI-906 demonstrated anti-proliferative effects in HCC cells lines overexpressing INSR and IGF-2 (88). Moreover, high mRNA expression of IGF-2/INSR correlated with EMT gene signature, which also was associated with increased sensitivity to OSI-906 (88). Taken together, overexpression of IGF-2/INSR predicts the EMT phenotype and response to OSI-906 in HCC cell lines, and offers a method targeting IGF-1R, INSR, and HR due to the high degree of homology in the kinase domain of these receptors.

\section{Insulin like Growth Factor Binding Proteins}

There are six high affinity superfamilies of IGF binding proteins (IGFBPs) that function as key regulators of the IGF pathway (Figure 1) (89). IGFBPs are an important consideration in IGF signaling potential, as they are key regulators in the bioavailability of circulating IGF ligands (90). More recently, IGFBPs have intracellular roles in regulating growth and survival, and intranuclear roles in transcription regulation, induction of apoptosis, and DNA damage repair (91-93). In circulation, IGFBPs 1-5 has the same affinities to IGF-1 and IGF-2, while IGFBP-6 has a binding preference for IGF-2 (90). The binding affinity of IGFBPs to IGF ligand is similar to the binding affinity of IGFs to IGF-1R (94-97). The key function of circulation IGFBPs, especially with IGFBP3 and to a smaller extent IGFBP-5, is to form ternary complexes, including IGFs, IGFBPs, and the acid-labile subunit (ALS) (98). These complexes not only account for the major circulating IGFs but also increase the half-life of unbound IGFs from a few minutes up to 16-24 h (98-100). Since, IGFBPs have a sequestration affect that limits bioavailability of circulating IGFs and competitively inhibits IGFs to bind with IGF-1R at pericellular region, leading to the tumor suppressor action of IGFBPs. 
IGFBP-3 and IGFBP-5 are also well established as inhibitory effect on tumor growth via an IGF-independent mechanism (101-103). The type V transforming growth factor- $\beta$ (TGF- $\beta$ ) receptor (also known as low density lipoprotein receptor-related protein 1; LRP1) is implicated as a binding receptor of IGFBP-3 and possibly, to a lesser extent, IGFBP-5 (104). TGF- $\beta$ mediates growth inhibition by dephosphorylating insulin receptor substrate 2 (IRS-2) and stimulates Smad 2/3 (104-106). Moreover, at cell surface, the putative IGFBP-3 receptor (also known as transmembrane protein 219; TMEM219) is hypothesized to be death receptor, stimulating caspase 8 dissociating from its cytoplasmic tail upon ligand binding, and promoting apoptosis $(107,108)$. In endoplasmic reticulum, IGFBP-3 can form a complex with the chaperone protein GRP78 that induces apoptosis by competing with caspase 7 for GRP78 binding (109). The IGFBP-3-GRP78 complex has also been demonstrated to augment autophagy as a result of cellular stress; however, the mechanism for these is still unknown $(109,110)$. In addition, IGFBPs can be internalized to nucleus and have interactions with nuclear hormone receptors, including retinoid $\mathrm{X}$ receptor, retinoic acid receptor, and the vitamin $\mathrm{D}$ receptor $(93,111)$. Activation of these receptors induces transcription of IGFBP-3, IGFBP-4, IGFBP-5, and IGFBP-6, which results in growth inhibition (110-116). For example, IGFBP-3 can bind to retinoid $\mathrm{X}$ receptor, which induces pro-apoptotic transcription activity (93). IGFBP-3 is required for the formation of EGRF and DNA dependent kinase (DNA$\mathrm{PK}$ ) complex in nucleus to initiating DNA repair after DNA double-stand breaks following chemotherapy (92). IGFBP-3 is also directly phosphorylated by DNA-PK, which stimulates its binding to EGFR and leads to induction of apoptosis $(117,118)$. IGFBP-6 enhances SEMA3B, a member of class 3 semaphorins activity to inhibit vascular epithelium growth factor (VEGF). Therefore, expression of IGFBP-6 can result in suppression of angiogenesis (119).

Furthermore, mounting evidences are shown that IGFBPs may not be purely regulatory, but may also have oncogenic potential. IGFBP-1, IGFBP-2, and IGFBP-6 stimulate cell migration and metastasis by interacting with $\alpha 5$ integrin and prohibin 2 (120122). Similarly, in activated Kras background, overexpression of IGFBP-2 promotes tumor growth (123). IGFBP-2 also positively regulates $\beta$-catenin in Wnt signaling and integrin $\beta 1$-ERK, leading to pro tumorigenic effects $(124,125)$. In addition to intracellular activity, the nuclear import of IGFBP-2 increases activation of VEGF transcription resulting in increased angiogenesis (126). In the context of breast cancer, IGFBP-3 and IGFBP-5, secreted by carcinoma-associated fibroblasts (CAFs), inhibit detachmentinduced cell death, known as anoikis, via regulation of ERKMAPK activation (127).

The dichotomous effect of IGFBP-3 and IGFBP-5 may be explained by the "sphigolipid rheostat," which determines cell fate and their interaction with microenvironment. Ceremide and sphigosine mediate cell cycle arrest and cell death by autophagy; in contrast, sphigosine-1-phophate (S1P) promotes cell survival and proliferation (128). Sphigosine kinase (SK) generates S1P from sphigosine. S1P can transactivate various growth factor receptors, including EGFR and IGF-1R, by transportation to extracellular space then activating S1P receptor $(129,130)$. Exogenous IGFBP-5 stimulates SK in vitro, then increases the level of S1P that may contribute to survival effect; however, when fibronectin is present in cell culture, the survival effect of IGFBP-5 is lost (131). On the other hand, IGFBP-3 promotes ceramide induced cell death when cells are grown in vitro; however, when cells are grown on fibronectin, IGFBP-3 actions were reversed (131). IGFBP-3 also activates SK and increases phosphorylation of EGF in a triple negative breast cancer cell line (132).

\section{IGFBPs as Potential Predictive and Prognostic Biomarkers}

High level of circulating IGFBP-1 was associated with poor allcause mortality and cancer specific death in colorectal cancer patients (CRC) $(133,134)$. However, in a large Phase II study, this putative prognostic biomarker failed to be confirmed (135). In this and subsequent other studies, serum IGFBP-1 also did not demonstrate a predictive value for cancer risk in CRC, NSCLC, and endometrial cancer (136-140). In prostate cancer, high level of IGFBP-1 was associated with increased cancer risk and a shorter time to castration resistant prostate cancer from androgen deprivation therapy (ADT) and reduced OS $(141,142)$. This suggests that in prostate cancer, IGFBP-1 can both serve as a prognostic and predictive biomarker. In HCC, on the other hand, low tissue expression of IGFBP-1, assessed by IHC, was associated with decreased OS (143). With regards to treatment with the mAb cixutumumab, high serum IGFBP-1 predicted improvement in PFS and OS in HCC patients (144). However, high circulating levels of IGFBP-1 failed to predict response to mAb against IGF-1R, ganitumab, in CRC (135). There are conflicting data concerning the predictive and prognostic value of IGFBP-1 as a biomarker, and further studies in a variety of tumor types are necessary.

There is strong evidence of an association between gliomas and IGFBP-2. Both high levels of serum IGFBP-2 and high tissue expression IGFBP-2 by both IHC and mRNA levels correlate with poor PFS and OS in gliomas, including glioblastoma multiforme (GBM) (145-149). Similarly, associations exist in CRC, where high serum IGFBP-2 correlated with increased mortality rate (135, $150,151)$. Nonetheless, the prognostic potential of circulating IGFBP-2 in CRC was not demonstrated in other studies (134, 137). In addition, circulating IGFBP-2 did not predict response to ganitumab in CRC patients (151). High serum levels and high IHC score of IGFBP-2 in NSCLC were also associated with poor OS $(152,153)$. In contrast, high serum level of IGFBP-2 was associated with better OS in adrenocortical carcinoma (154). Low serum level of IGFBP-2 in advanced pancreatic cancer predicted the improvement of OS from ganitumab and gemcitabine (155). The role of IGFBP-2 as a potential biomarker for prostate cancer was evaluated in a large case control study; however, serum IGFBP2 did not predict risk of prostate cancer (156). There was no association between serum level of IGFBP-2 and cancer risk in endometrial and ovarian cancer $(138,157)$. IGFBP-2 was shown to contribute to ovarian cancer cells invasion in vitro (158). Clinically, an elevated serum level of IGFBP-2 was shown to correspond with poorer prognosis, suggesting prognostic value of IGFBP-2 in ovarian cancer (159). Furthermore, in vitro treatment of ovarian cancer cells with IGFBP-2 was shown to stimulate cell growth and 
potentiated the activation of multiple signaling pathways involved in cell proliferation (160). Similar to IGFBP-1, studies examining the prognostic and predictive value of IGFBP-2 as a biomarker are conflicted and require further studies to clarify its value in specific tumor types.

The most abundant IGF binding protein is IGFBP-3, and thus, many studies have focus on IGFBP-3 level and/or its ratio to the IGF-1 ligand, which may represent the inactive fraction of circulating IGF ligand. In one large case control study, high serum IGFBP-3 was associated with lower risk of CRC; however, several other studies failed to demonstrate this same association (133137, 140, 161). High serum IGFBP-3 in CRC patients also did not predict response to ganitumab, however did correlate with poor PFS and OS (151). In breast cancer, the data regarding IGFBP-3 are conflicting. Some studies have reported that high serum levels of IGFBP-3 are associated with increased risk of breast cancer in pre- and or post-menopausal women $(162,163)$; however, several studies were unable to confirm this finding (164-167). The ratio between IGF-1 and serum IGFBP-3 was associated with increased mortality, suggesting a potential prognostic biomarker value of this ratio in breast cancer (167). In addition, levels of IGFBP3 in breast cancer tissue, determined by IHC but not mRNA levels, were associated with poor OS $(168,169)$. A small cohort study in breast cancer examining serum IGFBP-3 levels before and 1 week after palliative chemotherapy demonstrated that patients who showed decreased IGFBP-3 levels after treatment showed poorer OS (170). In prostate cancer, high serum level of IGFBP3 correlated with increased cancer risk and cancer specific death (156, 171-173). Expression of nuclear IGFBP-3 in prostatic cancer tissue was also associated with decreased PFS time (174). However, other studies have failed to confirm the predictive value of circulating IGFBP-3 for increased risk of prostate cancer (175, 176). In NSCLC, data more consistently demonstrate that high levels of serum IGFBP-3 are associated with a better prognosis for PFS and OS (177-179). Moreover, decreased expression of IGFBP3 from stage I NSCLC tissue was associated with poor PFS (180). In other cancer types, specifically ovarian, endometrial, pancreatic, gastric, and renal cancer, no association was demonstrated between serum IGFBP-3 and cancer risk (157, 181-187). In other cancer types, specifically in squamous cell carcinoma of esophagus and tongue, gastric cancer, HCC, and ovarian endometrioid cancer including, low tissue expression of IGBP-3 was associated with poor disease outcome (PFS or OS) (188-192). In GBM tissue, high IHC expression of IGFBP-3 was related to poor OS (193). High serum level of IGFBP-3 in advanced pancreatic cancer predicted the improvement in OS as a result of combined treatment with ganitumab and gemcitabine (155). In contrast, circulating IGFBP-3 did not correlate with a response to ganitumab in CRC, and the combination of cixutumumab and the mTOR inhibitor, temsirolimus, in other solid tumor patients $(151,194)$.

In breast cancer, high IHC staining for IGFBP-4 was associated with longer PFS and OS (195). However, serum IGFBP-4 was not associated with cancer risk for NSCLC (139). Additionally, a small study demonstrated that IGFBP-4 levels were inversely correlated with survival across all stages of epithelial ovarian cancer (196). There has been no work publishing relationship between IGFBP4 and response to IGF targeting agents. Unlike the other IGFBPs, few studies exist, examining IGFBP4 as a biomarker and might represent an under-explored biomarker for predicting response to IGF-1R targeted therapies.

Low circulation IGFBP-5 was associated with poor PFS in NSCLC (139). In breast cancer, high tissue expression by IHC or mRNA levels correlated with decreased PFS and OS $(195,197$, 198). Furthermore, a high mRNA ratio of IGFBP-5/IGFBP-4 from patients' tissue enhanced the power of its poor prognostic value, and also predicted resistance to the IGF-1R and INSR TKI, BMS536924, in a breast cancer cell line (197). After tamoxifen treatment, low IGFBP-5 IHC expression correlated with poor OS (199). In breast cancer patients, high serum levels of IGFBP- 5 correlated with improved time to treatment failure of cixutumumab (200). Collectively, the tissue level of IGFBP-5 in breast cancer may be both prognostic and predictive biomarker for tamoxifen and IGF inhibitory agents. IGFBP-5 overexpression by IHC in urothelial carcinomas of upper urinary tracts and urinary bladder was associated with poor prognosis (201). Recently, low IGFBP-5 mRNA expression in 93 cancer cell lines predicted a good response to figitumumab in vitro (202). Hence, the prognostic and predictive value of IGFBP-5 is encouraging and further study evaluating IGFBP- 5 mRNA levels as a potential biomarker for IGF-1R mAbs is warranted.

There is no study that directly investigated IGFBP- 6 as a potential biomarker. As a biomarker, there is no consistent evidence from pre-clinical and clinical studies suggesting the value of IGFBPs to predict outcome or response to IGF targeted treatments. It may due to the considerable complexity of the IGF-IGFBPs system and their interaction with other pathways. Despite contradictory results of IGFBPs, further studies are needed, investigating the potential prognostic biomarker value that might need to be tailor for each IGFBP and cancer type.

\section{Nuclear IGF-1R}

It is now well recognized that RTKs can translocate to the nucleus, and this was first shown for EGFR (203-205). Nuclear EGFR is capable of directly regulating gene transcription and also interacts with DNA-dependent protein kinase catalytic subunit (DNAPKcs), a protein central to DNA repair by non-homologous end joining (NHEJ) (204, 206). Once inside the nucleus, EGFR functions as a co-transcription factor for several genes involved in cell proliferation and angiogenesis, and as a tyrosine kinase to activate and stabilize proliferating cell nuclear antigens and DNA dependent protein kinases (207). More recently, IGF-1R has been shown to translocate to the nucleus in cancers for the prostate, renal, breast, soft tissue sarcomas, and Ewing sarcomas (208-210).

Following activation, IGF-1R is known to be internalized by clathrin- and caveolin-mediated endocytosis (211, 212). Upon internalization, IGF-1R is transported to recycling endosomes where it is either recycled and shuttled back to the cell surface or transported to lysosomes for degradation (213). Work by Aleksic and colleagues showed that IGF-1 can stimulate liganddependent internalization and nuclear translocation of full-length IGF-1R subunits in prostate cancer cells (208). Nuclear translocation was also demonstrated in melanoma cells by Sehat et al., who also reported that IGF-1R nuclear translocation requires 
SUMOylation on three evolutionarily conserved lysine residues (K1025, K1100, K1120) in the beta subunit (214). Typically, proteins that are transported to the nucleus contain a nuclear localization sequence (NLS), which allows binding to importins for translocation through nuclear pores (215). The IGF-1R does not contain an NLS; however, Packham et al. recently demonstrated that IGF-1R first associated with the dynactin subunit p150 Glued, which transports the receptor to the nuclear pore complex, where it co-localizes with importin- $\beta$. Similarly, the function of nuclear IGF-1R is unclear. Sehat et al. conducted a ChIP-sequencing experiment and identified IGF-1R binding sites in the genome, but these were few $(\sim 500)$ and most were remote from known genes (214). Recent studies have shown that nuclear IGF-1R can bind to LEF1 transcription factor and increase the promoter activity of LEF1 target genes including cyclin D1, which might be an additional mechanism by which IGF-1R promotes proliferation (210). In addition, IGF-1R/INSR HR are reported to localize to the nucleus of corneal epithelial cells (216).

Work by Aleksic and colleagues showed that higher levels of nuclear IGF-1R were associated with poor prognosis in renal cancer, suggesting that nuclear IGF-1R contributes to an aggressive phenotype (208). Recent studies in HCC treated with the EGFR inhibitor gefitinib showed increased levels of nuclear IGF$1 \mathrm{R}$ following treatment (217). The IGF-1R nuclear translocation was enhanced under gefitinib treatment and increased in a dosedependent manner. This suggests that nuclear IGF-1R translocation following gefitinib treatment may contribute to resistance to IGF-targeting agents (217). Studies in a small group of patients with sarcomas treated with several IGF-1R monoclonal antibodies found that exclusive nuclear IGF-1R was associated with better PFS and PS (218). This suggests that exclusive nuclear IGF$1 \mathrm{R}$ staining might serve as a predictive biomarker for sarcoma patients likely to benefit from IGF-1R mAb therapy (218). Initial studies of nuclear IGF-1R point toward a role in transcription and regulation of the cell cycle; however, the complex role of nuclear IGF-1R is yet to be fully understood and research identifying its function and regulation in the nucleus will provide for the development of rational combination treatment in cancers that develop drug resistance.

\section{Biomarkers Based on Genetic Alterations Outside IGF-1R Signaling}

IGF-1R accomplishes a wide range of functions via a complex signaling cascade, which raises the possibility of identifying biomarkers outside the immediate IGF axis. To support this idea, a study was reported using an unbiased siRNA screen to identify factors that regulate sensitivity to IGF-1R inhibition in childhood sarcomas. This work used the small molecule IGF1R inhibitor BMS-536924 and screened a library of 88 RTKs and 31 Insulin/IGF signaling pathways proteins and identified ribosomal S6 and macrophage-stimulating 1 receptor tyrosine kinase (MSTR1R) (219). In this report, BMS-536924 failed to block RPS6 activation in resistant sarcoma cell lines; however, this siRNA targeting RPS6 restored BMS-53924 efficacy (219). Recently, work by Gao et al. performed an unbiased siRNA screen to identify factors that regulate sensitivity to a IGF-1R inhibitor
(AZ12253801) in prostate cancer cells and breast cancer cells (220). Using this approach, two candidate biomarkers were validated, Dsh Homolog DVL3, apart of the WNT signaling pathway, and RAD51 required to strand invasion step of homologous recombination $(220,221)$. In both these reports, inhibition or genetic manipulation of DVL3 or RAD51 increased the sensitivity of tumor cells to IGF-1R inhibition, representing a subset of patients who might benefit from IGF-1R inhibition. Taken together, these studies in childhood sarcomas, and prostate, and breast cancers suggest that more studies are needed to investigate the potential of components outside the IGF axis to provide valuable predictive biomarkers for IGF-1R inhibition.

In addition to these screens, the breast cancer susceptibility genes, BRCA1 and BRCA2, have recently been shown to regular IGF-1R expression or influence the downstream signaling. In vitro work in MCF7 breast cancer cells demonstrated that BRCA1 knockdown induces the expression of IGF-1 mRNA in an estrogen receptor $\alpha$-dependent manner, which was shown to correspond with increased IGF-1R activation and signaling (222). In a study examining women with $B R C A 1$ and $B R C A 2$ mutation reported significant association in variants in IGF1R and IRS1 in $B R C A 1$ mutant carriers and also variants in IGFBP2 for BRCA2 carriers (223). Taken together, this suggests that tumors harboring mutations or deletions in BRCA 1/2 genes might be more sensitive to IGF-1R blockade. Further studies examining BRCA1 and BRCA2 status as a predictive biomarker for IGF-1R inhibition are warranted.

\section{Expression Profiles}

Given the complexity of growth factor signaling, it is conceivable that there might not be a single predictive biomarker but rather a combination of multiple factors. The use of a gene expression patterns has been previously reported in breast cancer, in which IGF- 1 treated MCF-7 cells were profiled for RNA transcription 3 and $24 \mathrm{~h}$ following treatment (224). In this report, IGF-1 treatment induced changes in the expression of genes associated with proliferation, metabolism, and DNA repair, and in particular, IGF-1 signature was enriched for transcriptional targets of $\mathrm{PI} 3 \mathrm{~K} / \mathrm{AKT} / \mathrm{mTOR}$ and Ras/MAP pathways (224). Similar profiles were observed in ER-negative breast tumors but also in $25 \%$ of ERpositive tumors, and tumors with this profile demonstrated poorer prognosis suggesting a predictive value in breast cancer (224). Subsequent work by Creighton et al. examined the transcriptional profile of the IGF-1R downstream signaling molecule PI3K and found that ER levels negatively correlated with PI3K activation levels both at the proteomic and transcriptional level (225). Treatment with a PI3K inhibitor resulted in decreased PI3K activity and increased ER expression in vitro, and thus might restore sensitivity to hormone therapy (225). This suggests that patients with ERnegative breast cancers might benefit from treatment with IGF inhibitory drugs, as IGF signaling is capable of directly influencing the activation of PI3K.

\section{Conclusion}

Compelling pre-clinical data supported the use of IGF-1R targeted therapies; however, in unselected phase $2 / 3$ clinical trails, IGF-1R 
targeted agents have shown little-to-no benefits. It is possible that the current generation of $\mathrm{mAbs}$ and small molecule inhibitors targeting the ligand binding domain or the intracellular kinase domain is not the correct approach, due to toxicity and hyperglycemia. Perhaps, a more effective approach is to limit the bioavailability of the ligands, IGF-1 and IGF-2, which inhibits IGF-induced IGF-1R and IR-A activation but does not affect insulin signaling. Such approach is currently being examined with the mAb MEDI-573 and BI 836845, which reduces proliferation and survival in vitro and in vivo $(226,227)$. The use of ligand mAbs as an approach to limit toxicity and hyperglycemia, while inhibiting IGF-1R/INSR-A mediated effects of tumor proliferation and survival, was supported by a Phase I trial using MEDI-573 (228). A total of 43 patients were treated with MEDI-573 at a dose greater than $5 \mathrm{mg} / \mathrm{kg}$ circulating levels of IGF-1 and IGF-II were fully suppressed (228). Moreover, BI 836845 enhanced the antitumor efficacy of rapamycin by blocking a rapamycin-induced increase in upstream signaling

\section{References}

1. Sell C, Dumenil G, Deveaud C, Miura M, Coppola D, DeAngelis T, et al. Effect of a null mutation of the insulin-like growth factor I receptor gene on growth and transformation of mouse embryo fibroblasts. Mol Cell Biol (1994) 14(6):3604-12.

2. Anderson JL, Denny CT, Tap WD, Federman N. Pediatric sarcomas: translating molecular pathogenesis of disease to novel therapeutic possibilities. Pediatr Res (2012) 72(2):112-21. doi:10.1038/pr.2012.54

3. Martins AS, Olmos D, Missiaglia E, Shipley J. Targeting the insulin-like growth factor pathway in rhabdomyosarcomas: rationale and future perspectives. Sarcoma (2011) 2011:209736. doi:10.1155/2011/209736

4. Kull FC Jr, Jacobs S, Su YF, Svoboda ME, Van Wyk JJ, Cuatrecasas P. Monoclonal antibodies to receptors for insulin and somatomedin-C. J Biol Chem (1983) 258(10):6561-6.

5. Rohlik QT, Adams D, Kull FC Jr, Jacobs S. An antibody to the receptor for insulin-like growth factor I inhibits the growth of MCF-7 cells in tissue culture. Biochem Biophys Res Commun (1987) 149(1):276-81. doi:10.1016/ 0006-291X(87)91635-4

6. Arteaga CL, Kitten LJ, Coronado EB, Jacobs S, Kull FC Jr, Allred DC, et al. Blockade of the type I somatomedin receptor inhibits growth of human breast cancer cells in athymic mice. J Clin Invest (1989) 84(5):1418-23. doi:10.1172/ JCI114315

7. Yee D. Insulin-like growth factor receptor inhibitors: baby or the bathwater? J Natl Cancer Inst (2012) 104(13):975-81. doi:10.1093/jnci/djs258

8. Hendrickson AW, Haluska P. Resistance pathways relevant to insulin-like growth factor-1 receptor-targeted therapy. Curr Opin Investig Drugs (2009) 10(10):1032-40.

9. Yuen JS, Macaulay VM. Targeting the type 1 insulin-like growth factor receptor as a treatment for cancer. Expert Opin Ther Targets (2008) 12(5):589-603. doi:10.1517/14728222.12.5.589

10. Sachdev D, Li SL, Hartell JS, Fujita-Yamaguchi Y, Miller JS, Yee D. A chimeric humanized single-chain antibody against the type I insulin-like growth factor (IGF) receptor renders breast cancer cells refractory to the mitogenic effects of IGF-I. Cancer Res (2003) 63(3):627-35.

11. Sachdev D, Singh R, Fujita-Yamaguchi Y, Yee D. Down-regulation of insulin receptor by antibodies against the type I insulin-like growth factor receptor: implications for anti-insulin-like growth factor therapy in breast cancer. Cancer Res (2006) 66(4):2391-402. doi:10.1158/0008-5472.CAN-05-3126

12. King H, Aleksic T, Haluska P, Macaulay VM. Can we unlock the potential of IGF-1R inhibition in cancer therapy? Cancer Treat Rev (2014) 40(9):1096-105. doi:10.1016/j.ctrv.2014.07.004

13. Hewish M, Chau I, Cunningham D. Insulin-like growth factor 1 receptor targeted therapeutics: novel compounds and novel treatment strategies for in vitro as well as in human tumor xenograft models in nude mice (226). Additionally, the lack of clinically effective IGF targeted therapies might be a result of the lack of predictive biomarker. Various pre-clinical studies have suggested that IGF targeted agents might benefit patients of specific molecular background. For example, patients with triple negative breast cancer or KRAS-mutant lung cancers might benefit from IGF-1R inhibitor drugs (229-231). The challenge in unlocking the potential for IGF targeted therapies lies in the need of predictive biomarkers.

\section{Acknowledgments}

This work was supported by fellowships and grants from the United States National Institute of Health Grants: R01 CA184502 (PH) and Mayo Clinic SPORE in Breast Cancer CA116201 (PH), Minnesota Partnership for Biotechnology and Medical Genomics $(\mathrm{PH}, \mathrm{KL})$, and Ginkgo, LLC (PH).

cancer medicine. Recent Pat Anticancer Drug Discov (2009) 4(1):54-72. doi:10. 2174/157489209787002515

14. Gualberto A, Karp DD. Development of the monoclonal antibody figitumumab, targeting the insulin-like growth factor-1 receptor, for the treatment of patients with non-small-cell lung cancer. Clin Lung Cancer (2009) 10(4):273-80. doi:10.3816/CLC.2009.n.038

15. Karp DD, Paz-Ares LG, Novello S, Haluska P, Garland L, Cardenal F, et al. Phase II study of the anti-insulin-like growth factor type 1 receptor antibody CP-751,871 in combination with paclitaxel and carboplatin in previously untreated, locally advanced, or metastatic non-small-cell lung cancer. J Clin Oncol (2009) 27(15):2516-22. doi:10.1200/JCO.2008.19.9331

16. Basu B, Olmos D, de Bono JS. Targeting IGF-1R: throwing out the baby with the bathwater? Br J Cancer (2011) 104(1):1-3. doi:10.1038/sj.bjc.6606023

17. Buck E, Mulvihill M. Small molecule inhibitors of the IGF-1R/IR axis for the treatment of cancer. Expert Opin Investig Drugs (2012) 20(5):605-21. doi:10. 1517/13543784.2011.558501

18. Pollak M. The insulin and insulin-like growth factor receptor family in neoplasia: an update. Nat Rev Cancer (2012) 12(3):159-69. doi:10.1038/nrc3215

19. Dupont J, LeRoith D. Insulin and insulin-like growth factor I receptors: similarities and differences in signal transduction. Horm Res (2001) 55(Suppl 2):22-6. doi:10.1159/000063469

20. De Meyts P. The insulin receptor: a prototype for dimeric, allosteric membrane receptors? Trends Biochem Sci (2008) 33(8):376-84. doi:10.1016/j.tibs. 2008.06.003

21. Moller DE, Yokota A, Caro JF, Flier JS. Tissue-specific expression of two alternatively spliced insulin receptor mRNAs in man. Mol Endocrinol (1989) 3(8):1263-9. doi:10.1210/mend-3-8-1263

22. Benecke H, Flier JS, Moller DE. Alternatively spliced variants of the insulin receptor protein. Expression in normal and diabetic human tissues. J Clin Invest (1992) 89(6):2066-70. doi:10.1172/JCI115819

23. Giddings SJ, Carnaghi LR. Insulin receptor gene expression during development: developmental regulation of insulin receptor mRNA abundance in embryonic rat liver and yolk sac, developmental regulation of insulin receptor gene splicing, and comparison to abundance of insulin-like growth factor 1 receptor mRNA. Mol Endocrinol (1992) 6(10):1665-72.

24. Frasca F, Pandini G, Scalia P, Sciacca L, Mineo R, Costantino A, et al. Insulin receptor isoform A, a newly recognized, high-affinity insulin-like growth factor II receptor in fetal and cancer cells. Mol Cell Biol (1999) 19(5):3278-88.

25. Mosthaf L, Grako K, Dull TJ, Coussens L, Ullrich A, McClain DA. Function ally distinct insulin receptors generated by tissue-specific alternative splicing EMBO J (1990) 9(8):2409-13.

26. Yamaguchi Y, Flier JS, Benecke H, Ransil BJ, Moller DE. Ligand-binding properties of the two isoforms of the human insulin receptor. Endocrinology (1993) 132(3):1132-8. doi:10.1210/en.132.3.1132 
27. Wang CF, Zhang G, Zhao LJ, Qi WJ, Li XP, Wang JL, et al. Overexpression of the insulin receptor isoform A promotes endometrial carcinoma cell growth. PLoS One (2013) 8(8):e69001. doi:10.1371/journal.pone.0069001

28. Louvi A, Accili D, Efstratiadis A. Growth-promoting interaction of IGF-II with the insulin receptor during mouse embryonic development. Dev Biol (1997) 189(1):33-48. doi:10.1006/dbio.1997.8666

29. Benyoucef S, Surinya KH, Hadaschik D, Siddle K. Characterization of insulin/IGF hybrid receptors: contributions of the insulin receptor L2 and Fn1 domains and the alternatively spliced exon 11 sequence to ligand binding and receptor activation. Biochem J (2007) 403(3):603-13. doi:10.1042/BJ20061709

30. Malaguarnera R, Sacco A, Voci C, Pandini G, Vigneri R, Belfiore A. Proinsulin binds with high affinity the insulin receptor isoform $A$ and predominantly activates the mitogenic pathway. Endocrinology (2012) 153(5):2152-63. doi:10. 1210/en.2011-1843

31. Taniguchi CM, Emanuelli B, Kahn CR. Critical nodes in signalling pathways: insights into insulin action. Nat Rev Mol Cell Biol (2006) 7(2):85-96. doi:10. 1038/nrm 1837

32. Cohen $P$. The twentieth century struggle to decipher insulin signalling. Nat Rev Mol Cell Biol (2006) 7(11):867-73. doi:10.1038/nrm2043

33. Barbieri M, Bonafè M, Franceschi C, Paolisso G. Insulin/IGF-I-signaling pathway: an evolutionarily conserved mechanism of longevity from yeast to humans. Am J Physiol Endocrinol Metab (2003) 285(5):E1064-71. doi:10.1152/ ajpendo.00296.2003

34. Cheng Z, Tseng Y, White MF. Insulin signaling meets mitochondria in metabolism. Trends Endocrinol Metab (2010) 21(10):589-98. doi:10.1016/j. tem.2010.06.005

35. Taguchi A, White MF. Insulin-like signaling, nutrient homeostasis, and life span. Annu Rev Physiol (2008) 70:191-212. doi:10.1146/annurev.physiol.70. 113006.100533

36. Nakae J, Kido Y, Accili D. Distinct and overlapping functions of insulin and IGF-I receptors. Endocr Rev (2001) 22(6):818-35. doi:10.1210/edrv.22.6.0452

37. Perks CM, Vernon EG, Rosendahl AH, Tonge D, Holly JM. IGF-II and IGFBP2 differentially regulate PTEN in human breast cancer cells. Oncogene (2007) 26(40):5966-72. doi:10.1038/sj.onc.1210397

38. Pandini G, Medico E, Conte E, Sciacca L, Vigneri R, Belfiore A. Differential gene expression induced by insulin and insulin-like growth factor-II through the insulin receptor isoform A. J Biol Chem (2003) 278(43):42178-89. doi:10. 1074/jbc.M304980200

39. Morcavallo A, Gaspari M, Pandini G, Palummo A, Cuda G, Larsen MR, et al. Research resource: new and diverse substrates for the insulin receptor isoform A revealed by quantitative proteomics after stimulation with IGF-II or insulin. Mol Endocrinol (2011) 25(8):1456-68. doi:10.1210/me.2010-0484

40. Liang J, Slingerland JM. Multiple roles of the PI3K/PKB (Akt) pathway in cell cycle progression. Cell Cycle (2003) 2(4):339-45. doi:10.4161/cc.2.4.433

41. Vella V, Pandini G, Sciacca L, Mineo R, Vigneri R, Pezzino V, et al. A novel autocrine loop involving IGF-II and the insulin receptor isoform-A stimulates growth of thyroid cancer. J Clin Endocrinol Metab (2002) 87(1):245-54. doi:10. 1210/jcem.87.1.8142

42. Vella V, Sciacca L, Pandini G, Mineo R, Squatrito S, Vigneri R, et al. The IGF system in thyroid cancer: new concepts. Mol Pathol (2001) 54(3):121-4. doi:10.1136/mp.54.3.121

43. Papa V, Pezzino V, Costantino A, Belfiore A, Giuffrida D, Frittitta L, et al. Elevated insulin receptor content in human breast cancer. J Clin Invest (1990) 86(5):1503-10. doi:10.1172/JCI114868

44. Kalla Singh S, Brito C, Tan QW, De León M, De León D. Differential expression and signaling activation of insulin receptor isoforms $\mathrm{A}$ and $\mathrm{B}$ : a link between breast cancer and diabetes. Growth Factors (2011) 29(6):278-89. doi:10.3109/08977194.2011.616200

45. Kalli KR, Falowo OI, Bale LK, Zschunke MA, Roche PC, Conover CA. Functional insulin receptors on human epithelial ovarian carcinoma cells: implications for IGF-II mitogenic signaling. Endocrinology (2002) 143(9):3259-67. doi:10.1210/en.2001-211408

46. Diaz LE, Chuan YC, Lewitt M, Fernandez-Perez L, Carrasco-Rodríguez S, Sanchez-Gomez M, et al. IGF-II regulates metastatic properties of choriocarcinoma cells through the activation of the insulin receptor. Mol Hum Reprod (2007) 13(8):567-76. doi:10.1093/molehr/gam039

47. Novosyadlyy R, Vijayakumar A, Lann D, Fierz Y, Kurshan N, LeRoith D. Physical and functional interaction between polyoma virus middle $\mathrm{T}$ antigen and insulin and IGF-I receptors is required for oncogene activation and tumour initiation. Oncogene (2009) 28(39):3477-86. doi:10.1038/onc.2009.209

48. Liu JJ, Druta M, Shibata D, Coppola D, Boler I, Elahi A, et al. Metabolic syndrome and colorectal cancer: is hyperinsulinemia/insulin receptor-mediated angiogenesis a critical process? J Geriatr Oncol (2014) 5(1):40-8. doi:10.1016/ j.jgo.2013.11.004

49. Bendall SC, Stewart MH, Menendez P, George D, Vijayaragavan K, Werbowetski-Ogilvie T, et al. IGF and FGF cooperatively establish the regulatory stem cell niche of pluripotent human cells in vitro. Nature (2007) 448(7157):1015-21. doi:10.1038/nature06027

50. Ziegler AN, Schneider JS, Qin M, Tyler WA, Pintar JE, Fraidenraich D, et al. IGF-II promotes stemness of neural restricted precursors. Stem Cells (2012) 30(6):1265-76. doi:10.1002/stem.1095

51. Ziegler AN, Chidambaram S, Forbes BE, Wood TL, Levison SW. Insulin-like growth factor-II (IGF-II) and IGF-II analogs with enhanced insulin receptora binding affinity promote neural stem cell expansion. J Biol Chem (2014) 289(8):4626-33. doi:10.1074/jbc.M113.537597

52. Shan J, Shen J, Liu L, Xia F, Xu C, Duan G, et al. Nanog regulates self-renewal of cancer stem cells through the insulin-like growth factor pathway in human hepatocellular carcinoma. Hepatology (2012) 56(3):1004-14. doi:10.1002/hep. 25745

53. Kosaki A, Webster NJ. Effect of dexamethasone on the alternative splicing of the insulin receptor mRNA and insulin action in HepG2 hepatoma cells. J Biol Chem (1993) 268(29):21990-6.

54. Andres SF, Simmons JG, Mah AT, Santoro MA, Van Landeghem L, Lund PK. Insulin receptor isoform switching in intestinal stem cells, progenitors, differentiated lineages and tumors: evidence that IR-B limits proliferation. J Cell Sci (2013) 126(Pt 24):5645-56. doi:10.1242/jcs.132985

55. Malaguarnera R, Frasca F, Garozzo A, Gianí F, Pandini G, Vella V, et al Insulin receptor isoforms and insulin-like growth factor receptor in human follicular cell precursors from papillary thyroid cancer and normal thyroid. J Clin Endocrinol Metab (2011) 96(3):766-74. doi:10.1210/jc.2010-1255

56. Jiang L, Zhu W, Streicher K, Morehouse C, Brohawn P, Ge X, et al. Increased IR-A/IR-B ratio in non-small cell lung cancers associates with lower epithelial-mesenchymal transition signature and longer survival in squamous cell lung carcinoma. BMC Cancer (2014) 14:131. doi:10.1186/ 1471-2407-14-131

57. Neuvians TP, Gashaw I, Hasenfus A, Hacherhäcker A, Winterhager E, Grobholz R. Differential expression of IGF components and insulin receptor isoforms in human seminoma versus normal testicular tissue. Neoplasia (2005) 7(5):446-56. doi:10.1593/neo.04643

58. Cox ME, Gleave ME, Zakikhani M, Bell RH, Piura E, Vickers E, et al. Insulin receptor expression by human prostate cancers. Prostate (2009) 69(1):33-40. doi:10.1002/pros.20852

59. Heni M, Hennenlotter J, Scharpf M, Lutz SZ, Schwentner C, Todenhöfer T, et al. Insulin receptor isoforms $\mathrm{A}$ and $\mathrm{B}$ as well as insulin receptor substrates1 and -2 are differentially expressed in prostate cancer. PLoS One (2012) 7(12):e50953. doi:10.1371/journal.pone.0050953

60. Huang J, Morehouse C, Streicher K, Higgs BW, Gao J, Czapiga M, et al. Altered expression of insulin receptor isoforms in breast cancer. PLoS One (2011) 6(10):e26177. doi:10.1371/journal.pone.0026177

61. Chettouh H, Fartoux L, Aoudjehane L, Wendum D, Clapéron A, Chrétien Y, et al. Mitogenic insulin receptor-A is overexpressed in human hepatocellular carcinoma due to EGFR-mediated dysregulation of RNA splicing factors. Cancer Res (2013) 73(13):3974-86. doi:10.1158/0008-5472.CAN-12-3824

62. De Meyts P, Palsgaard J, Sajid W, Theede AM, Aladdin H. Structural biology of insulin and IGF-1 receptors. Novartis Found Symp (2004) 262:160-71; discussion 171-6, 265-8.

63. Werner H, Weinstein D, Bentov I. Similarities and differences between insulin and IGF-I: structures, receptors, and signalling pathways. Arch Physiol Biochem (2008) 114(1):17-22. doi:10.1080/13813450801900694

64. Kissau L, Stahl P, Mazitschek R, Giannis A, Waldmann H. Development of natural product-derived receptor tyrosine kinase inhibitors based on conservation of protein domain fold. J Med Chem (2003) 46(14):2917-31. doi:10. 1021/jm0307943

65. Blanquart C, Achi J, Issad T. Characterization of IRA/IRB hybrid insulin receptors using bioluminescence resonance energy transfer. Biochem Pharmacol (2008) 76(7):873-83. doi:10.1016/j.bcp.2008.07.027 
66. Pandini G, Vigneri R, Costantino A, Frasca F, Ippolito A, Fujita-Yamaguchi $\mathrm{Y}$, et al. Insulin and insulin-like growth factor-I (IGF-I) receptor overexpression in breast cancers leads to insulin/IGF-I hybrid receptor overexpression: evidence for a second mechanism of IGF-I signaling. Clin Cancer Res (1999) 5(7):1935-44.

67. Pandini G, Frasca F, Mineo R, Sciacca L, Vigneri R, Belfiore A. Insulin/insulinlike growth factor I hybrid receptors have different biological characteristics depending on the insulin receptor isoform involved. J Biol Chem (2002) 277(42):39684-95. doi:10.1074/jbc.M202766200

68. Slaaby R, Schäffer L, Lautrup-Larsen I, Andersen AS, Shaw AC, Mathiasen IS, et al. Hybrid receptors formed by insulin receptor (IR) and insulin-like growth factor I receptor (IGF-IR) have low insulin and high IGF-1 affinity irrespective of the IR splice variant. J Biol Chem (2006) 281(36):25869-74. doi:10.1074/jbc.M605189200

69. Papa V, Gliozzo B, Clark GM, McGuire WL, Moore D, Fujita-Yamaguchi Y, et al. Insulin-like growth factor-I receptors are overexpressed and predict a low risk in human breast cancer. Cancer Res (1993) 53(16):3736-40.

70. Zhang H, Pelzer AM, Kiang DT, Yee D. Down-regulation of type I insulin-like growth factor receptor increases sensitivity of breast cancer cells to insulin. Cancer Res (2007) 67(1):391-7. doi:10.1158/0008-5472.CAN-06-1712

71. Mur C, Valverde AM, Kahn CR, Benito M. Increased insulin sensitivity in IGF-I receptor - deficient brown adipocytes. Diabetes (2002) 51(3):743-54. doi:10.2337/diabetes.51.3.743

72. Fulzele K, DiGirolamo DJ, Liu Z, Xu J, Messina JL, Clemens TL. Disruption of the insulin-like growth factor type 1 receptor in osteoblasts enhances insulin signaling and action. J Biol Chem (2007) 282(35):25649-58. doi:10.1074/jbc. M700651200

73. Dinchuk JE, Cao C, Huang F, Reeves KA, Wang J, Myers F, et al. Insulin receptor (IR) pathway hyperactivity in IGF-IR null cells and suppression of downstream growth signaling using the dual IGF-IR/IR inhibitor, BMS754807. Endocrinology (2010) 151(9):4123-32. doi:10.1210/en.2010-0032

74. Garofalo C, Manara MC, Nicoletti G, Marino MT, Lollini PL, Astolfi A, et al. Efficacy of and resistance to anti-IGF-1R therapies in Ewing's sarcoma is dependent on insulin receptor signaling. Oncogene (2011) 30(24):2730-40. doi:10.1038/onc. 2010.640

75. Vincent EE, Elder DJ, Curwen J, Kilgour E, Hers I, Tavaré JM. Targeting non-small cell lung cancer cells by dual inhibition of the insulin receptor and the insulin-like growth factor-1 receptor. PLoS One (2013) 8(6):e66963. doi:10.1371/journal.pone.0066963

76. Haluska P, Carboni JM, Loegering DA, Lee FY, Wittman M, Saulnier MG, et al. In vitro and in vivo antitumor effects of the dual insulin-like growth factorI/insulin receptor inhibitor, BMS-554417. Cancer Res (2006) 66(1):362-71. doi:10.1158/0008-5472.CAN-05-1107

77. Pollak M. Targeting insulin and insulin-like growth factor signalling in oncology. Curr Opin Pharmacol (2008) 8(4):384-92. doi:10.1016/j.coph.2008. 07.004

78. Harrington SC, Weroha SJ, Reynolds C, Suman VJ, Lingle WL, Haluska P. Quantifying insulin receptor isoform expression in FFPE breast tumors. Growth Horm IGF Res (2012) 22(3-4):108-15. doi:10.1016/j.ghir.2012.04.001

79. Santoro MA, Andres SF, Galanko JA, Sandler RS, Keku TO, Lund PK. Reduced insulin-like growth factor I receptor and altered insulin receptor isoform mRNAs in normal mucosa predict colorectal adenoma risk. Cancer Epidemiol Biomarkers Prev (2014) 23(10):2093-100. doi:10.1158/1055-9965. EPI-14-0177

80. Wang Y, Hua S, Tian W, Zhang L, Zhao J, Zhang H, et al. Mitogenic and anti-apoptotic effects of insulin in endometrial cancer are phosphatidylinositol 3-kinase/Akt dependent. Gynecol Oncol (2012) 125(3):734-41. doi:10.1016/j. ygyno.2012.03.012

81. Kim JS, Kim ES, Liu D, Lee JJ, Solis L, Behrens C, et al. Prognostic impact of insulin receptor expression on survival of patients with nonsmall cell lung cancer. Cancer (2012) 118(9):2454-65. doi:10.1002/cncr.26492

82. Mathieu MC, Clark GM, Allred DC, Goldfine ID, Vigneri R. Insulin receptor expression and clinical outcome in node-negative breast cancer. Proc Assoc Am Physicians (1997) 109(6):565-71.

83. Mulligan AM, O’Malley FP, Ennis M, Fantus IG, Goodwin PJ. Insulin receptor is an independent predictor of a favorable outcome in early stage breast cancer. Breast Cancer Res Treat (2007) 106(1):39-47. doi:10.1007/s10549-006-9471-x

84. Law JH, Habibi G, Hu K, Masoudi H, Wang MY, Stratford AL, et al. Phosphorylated insulin-like growth factor-i/insulin receptor is present in all breast cancer subtypes and is related to poor survival. Cancer Res (2008) 68(24):10238-46. doi:10.1158/0008-5472.CAN-08-2755

85. Pandini G, Wurch T, Akla B, Corvaia N, Belfiore A, Goetsch L. Functional responses and in vivo anti-tumour activity of h7C10: a humanised monoclonal antibody with neutralising activity against the insulin-like growth factor-1 (IGF-1) receptor and insulin/IGF-1 hybrid receptors. Eur J Cancer (2007) 43(8):1318-27. doi:10.1016/j.ejca.2007.03.009

86. Ulanet DB, Ludwig DL, Kahn CR, Hanahan D. Insulin receptor functionally enhances multistage tumor progression and conveys intrinsic resistance to IGF-1R targeted therapy. Proc Natl Acad Sci U S A (2010) 107(24):10791-8. doi:10.1073/pnas.0914076107

87. Kim JG, Kang MJ, Yoon YK, Kim HP, Park J, Song SH, et al. Heterodimerization of glycosylated insulin-like growth factor-1 receptors and insulin receptors in cancer cells sensitive to anti-IGF1R antibody. PLoS One (2012) 7(3):e33322. doi:10.1371/journal.pone.0033322

88. Zhao H, Desai V, Wang J, Epstein DM, Miglarese M, Buck E. Epithelialmesenchymal transition predicts sensitivity to the dual IGF-1R/IR inhibitor OSI-906 in hepatocellular carcinoma cell lines. Mol Cancer Ther (2012) 11(2):503-13. doi:10.1158/1535-7163.MCT-11-0327

89. Hwa V, Oh Y, Rosenfeld RG. The insulin-like growth factor-binding protein (IGFBP) superfamily. Endocr Rev (1999) 20:761-87. doi:10.1210/edrv.20. 6.0382

90. Baxter RC. IGF binding proteins in cancer: mechanistic and clinical insights. Nat Rev Cancer (2014) 14(5):329-41. doi:10.1038/nrc3720

91. Terrien X, Bonvin E, Corroyer S, Tabary O, Clement A, Henrion Caude A. Intracellular colocalization and interaction of IGF-binding protein-2 with the cyclin-dependent kinase inhibitor p21CIP1/WAF1 during growth inhibition. Biochem J (2005) 392(Pt 3):457-65. doi:10.1042/BJ20050517

92. Lin MZ, Marzec KA, Martin JL, Baxter RC. The role of insulin-like growth factor binding protein-3 in the breast cancer cell response to DNA-damaging agents. Oncogene (2014) 33(1):85-96. doi:10.1038/onc.2012.538

93. Liu B. Direct functional interactions between insulin-like growth factorbinding protein-3 and retinoid $\mathrm{X}$ receptor-[alpha] regulate transcriptional signaling and apoptosis. J Biol Chem (2000) 275:33607-13. doi:10.1074/jbc. M002547200

94. Beattie J. Molecular interactions in the insulin-like growth factor (IGF) axis: a surface plasmon resonance (SPR) based biosensor study. Mol Cell Biochem (2008) 307:221-36. doi:10.1007/s11010-007-9601-8

95. Headey SJ, Leeding KS, Norton RS, Bach LA. Contributions of the N- and Cterminal domains of IGF binding protein-6 to IGF binding. J Mol Endocrinol (2004) 33:377-86. doi:10.1677/jme.1.01547

96. Forbes BE, McCarthy P, Norton RS. Insulin-like growth factor binding proteins: a structural perspective. Front Endocrinol (Lausanne) (2012) 3:38. doi:10. 3389/fendo.2012.00038

97. Sitar T, Popowicz GM, Siwanowicz I, Huber R, Holak TA. Structural basis for the inhibition of insulin-like growth factors by insulin-like growth factorbinding proteins. Proc Natl Acad Sci U S A (2006) 103:13028-33. doi:10.1073/ pnas.0605652103

98. Baxter RC. Circulating levels and molecular distribution of the acid-labile ([alpha]) subunit of the high molecular weight insulin-like growth factorbinding protein complex. J Clin Endocrinol Metab (1990) 70:1347-53. doi:10. 1210/jcem-70-5-1347

99. Baxter RC. Circulating binding proteins for the insulinlike growth factors. Trends Endocrinol Metab (1993) 4:91-6. doi:10.1016/1043-2760(93) 90085-S

100. Baxter RC, Martin JL. Structure of the Mr 140,000 growth hormone-dependent insulin-like growth factor binding protein complex: determination by reconstitution and affinity-labeling. Proc Natl Acad Sci U S A (1989) 86:6898-902. doi:10.1073/pnas.86.18.6898

101. Silha JV. Insulin-like growth factor (IGF) binding protein-3 attenuates prostate tumor growth by IGF-dependent and IGF-independent mechanisms. Endocrinology (2006) 147:2112-21. doi:10.1210/en.2005-1270

102. Oh SH. Antimetastatic activity of insulin-like growth factor binding protein3 in lung cancer is mediated by insulin-like growth factor-independent urokinase-type plasminogen activator inhibition. Mol Cancer Ther (2006) 5:2685-95. doi:10.1158/1535-7163.MCT-06-0142

103. Tripathi G. IGF-independent effects of insulin-like growth factor binding protein-5 (Igfbp5) in vivo. FASEB J (2009) 23:2616-26. doi:10.1096/fj. 08- 114124 
104. Huang SS. Cellular growth inhibition by IGFBP-3 and TGF-[beta] 1 requires LRP-1. FASEB J (2003) 17:2068-81. doi:10.1096/fi.03-0256com

105. Leal SM, Huang SS, Huang JS. Interactions of high affinity insulin-like growth factor-binding proteins with the type $\mathrm{V}$ transforming growth factor-[beta] receptor in mink lung epithelial cells. J Biol Chem (1999) 274:6711-7. doi:10. $1074 / j b c .274 .10 .6711$

106. Fanayan S, Firth SM, Baxter RC. Signaling through the Smad pathway by insulin-like growth factor-binding protein-3 in breast cancer cells. Relationship to transforming growth factor-[beta] 1 signaling. J Biol Chem (2002) 277:7255-61. doi:10.1074/jbc.M108038200

107. Li C, Harada A, Oh Y. IGFBP-3 sensitizes antiestrogen-resistant breast cancer cells through interaction with GRP78. Cancer Lett (2012) 325(2):200-6. doi:10. 1016/j.canlet.2012.07.004

108. Ingermann AR. Identification of a novel cell death receptor mediating IGFBP3 -induced anti-tumor effects in breast and prostate cancer. J Biol Chem (2010) 285:30233-46. doi:10.1074/jbc.M110.122226

109. Grkovic S. IGFBP-3 binds GRP78, stimulates autophagy and promotes the survival of breast cancer cells exposed to adverse microenvironments. Oncogene (2013) 32:2412-20. doi:10.1038/onc.2012.264

110. Matilainen M, Malinen M, Saavalainen K, Carlberg C. Regulation of multiple insulin-like growth factor binding protein genes by 1 [alpha], 25dihydroxyvitamin D3. Nucleic Acids Res (2005) 33:5521-32. doi:10.1093/nar/ gki872

111. Shang Y, Baumrucker CR, Green MH. Signal relay by retinoic acid receptors [alpha] and [beta] in the retinoic acid-induced expression of insulin-like growth factor-binding protein-3 in breast cancer cells. J Biol Chem (1999) 274:18005-10. doi:10.1074/jbc.274.25.18005

112. Glantschnig H, Varga F, Klaushofer K. Thyroid hormone and retinoic acid induce the synthesis of insulin-like growth factor-binding protein-4 in mouse osteoblastic cells. Endocrinology (1996) 137:281-6. doi:10.1210/en.137.1.281

113. Higo H, Duan C, Clemmons DR, Herman B. Retinoic acid inhibits cell growth in HPV negative cervical carcinoma cells by induction of insulin-like growth factor binding protein-5 (IGFBP-5) secretion. Biochem Biophys Res Commun (1997) 239:706-9. doi:10.1006/bbrc.1997.7499

114. Uray IP. Rexinoid-induced expression of IGFBP-6 requires RAR[beta]dependent permissive cooperation of retinoid receptors and AP-1. J Biol Chem (2009) 284:345-53. doi:10.1074/jbc.M804721200

115. Schedlich LJ. Molecular basis of the interaction between IGFBP-3 and retinoid X receptor: role in modulation of RAR-signaling. Arch Biochem Biophys (2007) 465:359-69. doi:10.1016/j.abb.2007.06.013

116. Schedlich LJ, Muthukaruppan A, O'Han MK, Baxter RC. Insulin-like growth factor binding protein -5 interacts with the vitamin $\mathrm{D}$ receptor and modulates the vitamin D response in osteoblasts. Mol Endocrinol (2007) 21:2378-90. doi:10.1210/me.2006-0558

117. Schedlich LJ, Nilsen T, John AP, Jans DA, Baxter RC. Phosphorylation of insulin-like growth factor binding protein-3 by deoxyribonucleic aciddependent protein kinase reduces ligand binding and enhances nuclear accumulation. Endocrinology (2003) 144:1984-93. doi:10.1210/en.2002-220798

118. Cobb LJ, Liu B, Lee KW, Cohen P. Phosphorylation by DNA-dependent protein kinase is critical for apoptosis induction by insulin-like growth factor binding protein-3. Cancer Res (2006) 66:10878-84. doi:10.1158/0008-5472. CAN-06-0585

119. Koyama N, Zhang J, Huqun, Miyazawa H, Tanaka T, Su X, et al. Identification of IGFBP-6 as an effector of the tumor suppressor activity of SEMA3B. Oncogene (2008) 27(51):6581-9. doi:10.1038/onc.2008.263

120. Fu P, Yang Z, Bach LA. Prohibitin-2 binding modulates insulin-like growth factor-binding protein-6 (IGFBP-6)-induced rhabdomyosarcoma cell migration. J Biol Chem (2013) 288:29890-900. doi:10.1074/jbc.M113.510826

121. Jones JI. Insulin-like growth factor binding protein 1 stimulates cell migration and binds to the [alpha] 5 [beta] 1 integrin by means of its Arg-Gly-Asp sequence. Proc Natl Acad Sci U S A (1993) 90:10553-7. doi:10.1073/pnas.90. 22.10553

122. Wang GK, Hu L, Fuller GN, Zhang W. An interaction between insulin-like growth factor-binding protein 2 (IGFBP2) and integrin [alpha] 5 is essential for IGFBP2-induced cell mobility. J Biol Chem (2006) 281:14085-91. doi:10. 1074/jbc.M513686200

123. Dunlap SM. Insulin-like growth factor binding protein 2 promotes glioma development and progression. Proc Natl Acad Sci U S A (2007) 104:11736-41. doi:10.1073/pnas.0703145104
124. Sehgal P, Kumar N, Praveen Kumar VR, Patil S, Bhattacharya A, Vijaya Kumar M, et al. Regulation of protumorigenic pathways by insulin like growth factor binding protein 2 and its association along with beta-catenin in breast cancer lymph node metastasis. Mol Cancer (2013) 12:63. doi:10.1186/ 1476-4598-12-63

125. Han S, Li Z, Master LM, Master ZW, Wu A. Exogenous IGFBP-2 promotes proliferation, invasion, and chemoresistance to temozolomide in glioma cells via the integrin beta1-ERK pathway. Br J Cancer (2014) 111(7):1400-9. doi:10. 1038/bjc.2014.435

126. Azar WJ, Zivkovic S, Werther GA, Russo VC. IGFBP-2 nuclear translocation is mediated by a functional NLS sequence and is essential for its pro-tumorigenic actions in cancer cells. Oncogene (2014) 33:578-88. doi:10.1038/onc.2012.630

127. Weigel KJ, Jakimenko A, Conti BA, Chapman SE, Kaliney WJ, Leevy WM, et al. CAF-secreted IGFBPs regulate breast cancer cell anoikis. Mol Cancer Res (2014) 12(6):855-66. doi:10.1158/1541-7786.MCR-14-0090

128. Maceyka M, Harikumar KB, Milstien S, Spiegel S. Sphingosine-1-phosphate signaling and its role in disease. Trends Cell Biol (2012) 22(1):50-60. doi:10. 1016/j.tcb.2011.09.003

129. Sukocheva O. Estrogen transactivates EGFR via the sphingosine 1-phosphate receptor Edg-3: the role of sphingosine kinase-1. J Cell Biol (2006) 173:301-10. doi:10.1083/jcb.200506033

130. Pyne NJ, Pyne S. Sphingosine 1-phosphate and cancer. Nat Rev Cancer (2010) 10:489-503. doi:10.1038/nrc2875

131. McCaig C, Perks CM, Holly JM. Intrinsic actions of IGFBP- 3 and IGFBP- 5 on Hs578T breast cancer epithelial cells: inhibition or accentuation of attachment and survival is dependent upon the presence of fibronectin. J Cell Sci (2002) 115:4293-303. doi: $10.1242 /$ jcs. 00097

132. Martin JL, de Silva HC, Lin MZ, Scott CD, Baxter RC. Inhibition of insulinlike growth factor binding protein-3 signaling through sphingosine kinase 1 sensitizes triple-negative breast cancer cells to EGF receptor blockade. Mol Cancer Ther (2014) 13:316-28. doi:10.1158/1535-7163.MCT-13-0367

133. Wolpin BM, Meyerhardt JA, Chan AT, Ng K, Chan JA, Wu K, et al. Insulin, the insulin-like growth factor axis, and mortality in patients with nonmetastatic colorectal cancer. J Clin Oncol (2009) 27(2):176-85. doi:10.1200/ JCO.2008.17.9945

134. Kushlinskii NE, Gershtein ES, Nikolaev AA, Delektorskaya VV, Korotkova EA, Dvorova EK, et al. Insulin-like growth factors (IGF), IGF-binding proteins (IGFBP), and vascular endothelial growth factor (VEGF) in blood serum of patients with colorectal cancer. Bull Exp Biol Med (2014) 156(5):684-8. doi:10.1007/s10517-014-2425-0

135. Van Cutsem E, Eng C, Nowara E, Swieboda-Sadlej A, Tebbutt NC, Mitchell E, et al. Randomized phase $\mathrm{Ib} / \mathrm{II}$ trial of rilotumumab or ganitumab with panitumumab versus panitumumab alone in patients with wild-type KRAS metastatic colorectal cancer. Clin Cancer Res (2014) 20(16):4240-50. doi:10. 1158/1078-0432.CCR-13-2752

136. Ollberding NJ, Cheng I, Wilkens LR, Henderson BE, Pollak MN, Kolonel LN, et al. Genetic variants, prediagnostic circulating levels of insulin-like growth factors, insulin, and glucose and the risk of colorectal cancer: the Multiethnic Cohort study. Cancer Epidemiol Biomarkers Prev (2012) 21(5):810-20. doi:10. 1158/1055-9965.EPI-11-1105

137. Chi F, Wu R, Zeng YC, Xing R, Liu Y. Circulation insulin-like growth factor peptides and colorectal cancer risk: an updated systematic review and metaanalysis. Mol Biol Rep (2013) 40(5):3583-90. doi:10.1007/s11033-012-2432-z

138. Cust AE, Allen NE, Rinaldi S, Dossus L, Friedenreich C, Olsen A, et al. Serum levels of C-peptide, IGFBP-1 and IGFBP-2 and endometrial cancer risk; results from the European prospective investigation into cancer and nutrition. Int $J$ Cancer (2007) 120(12):2656-64. doi:10.1002/ijc.22578

139. Shersher DD, Vercillo MS, Fhied C, Basu S, Rouhi O, Mahon B, et al Biomarkers of the insulin-like growth factor pathway predict progression and outcome in lung cancer. Ann Thorac Surg (2011) 92(5):1805-11; discussion 1811. doi:10.1016/j.athoracsur.2011.06.058

140. Jiang B, Zhang X, Du LL, Wang Y, Liu DB, Han CZ, et al. Possible roles of insulin, IGF-1 and IGFBPs in initiation and progression of colorectal cancer. World J Gastroenterol (2014) 20(6):1608-13. doi:10.3748/wjg.v20.i6.1608

141. Sharma J, Gray KP, Evan C, Nakabayashi M, Fichorova R, Rider J, et al. Elevated insulin-like growth factor binding protein-1 (IGFBP-1) in men with metastatic prostate cancer starting androgen deprivation therapy (ADT) is associated with shorter time to castration resistance and overall survival. Prostate (2014) 74(3):225-34. doi:10.1002/pros.22744 
142. Cao Y, Nimptsch K, Shui IM, Platz EA, Wu K, Pollak MN, et al. Prediagnostic plasma IGFBP-1, IGF-1 and risk of prostate cancer. Int J Cancer (2014) 136(10):2418-26. doi:10.1002/ijc.29295

143. Dai B, Ruan B, Wu J, Wang J, Shang R, Sun W, et al. Insulin-like growth factor binding protein-1 inhibits cancer cell invasion and is associated with poor prognosis in hepatocellular carcinoma. Int J Clin Exp Pathol (2014) 7(9):5645-54.

144. Abou-Alfa GK, Capanu M, O’Reilly EM, Ma J, Chou JF, Gansukh B, et al. A phase II study of cixutumumab (IMC-A12, NSC742460) in advanced hepatocellular carcinoma. J Hepatol (2014) 60(2):319-24. doi:10.1016/j.jhep. 2013.09.008

145. Lin Y, Jiang T, Zhou K, Xu L, Chen B, Li G, et al. Plasma IGFBP-2 levels predict clinical outcomes of patients with high-grade gliomas. Neuro Oncol (2009) 11(5):468-76. doi:10.1215/15228517-2008-114

146. Gállego Pérez-Larraya J, Paris S, Idbaih A, Dehais C, Laigle-Donadey F, Navarro S, et al. Diagnostic and prognostic value of preoperative combined GFAP, IGFBP-2, and YKL-40 plasma levels in patients with glioblastoma. Cancer (2014) 120(24):3972-80. doi:10.1002/cncr.28949

147. Han S, Meng L, Han S, Wang Y, Wu A. Plasma IGFBP-2 levels after postoperative combined radiotherapy and chemotherapy predict prognosis in elderly glioblastoma patients. PLoS One (2014) 9(4):e93791. doi:10.1371/journal. pone.0093791

148. McDonald KL, O’Sullivan MG, Parkinson JF, Shaw JM, Payne CA, Brewer JM, et al. IQGAP1 and IGFBP2: valuable biomarkers for determining prognosis in glioma patients. J Neuropathol Exp Neurol (2007) 66(5):405-17. doi:10.1097/ nen.0b013e31804567d7

149. Scrideli CA, Carlotti CG Jr, Mata JF, Neder L, Machado HR, Oba-Sinjo SM, et al. Prognostic significance of co-overexpression of the EGFR/IGFBP-2/HIF2A genes in astrocytomas. J Neurooncol (2007) 83(3):233-9. doi:10.1007/ s11060-007-9328-0

150. Liou JM, Shun CT, Liang JT, Chiu HM, Chen MJ, Chen CC, et al. Plasma insulin-like growth factor-binding protein-2 levels as diagnostic and prognostic biomarker of colorectal cancer. J Clin Endocrinol Metab (2010) 95(4):1717-25. doi:10.1210/jc.2009-2668

151. Cohn AL, Tabernero J, Maurel J, Nowara E, Sastre J, Chuah BY, et al. A randomized, placebo-controlled phase 2 study of ganitumab or conatumumab in combination with FOLFIRI for second-line treatment of mutant KRAS metastatic colorectal cancer. Ann Oncol (2013) 24(7):1777-85. doi:10.1093/ annonc/mdt057

152. Guo C, Lu H, Gao W, Wang L, Lu K, Wu S, et al. Insulin-like growth factor binding protein-2 level is increased in blood of lung cancer patients and associated with poor survival. PLoS One (2013) 8(9):e74973. doi:10.1371/ journal.pone.0074973

153. Hu Q, Huang L, Kuang X, Zhang H, Ling G, Chen X, et al. Is insulin-like growth factor binding protein 2 associated with metastasis in lung cancer? Clin Exp Metastasis (2014) 31(5):535-41. doi:10.1007/s10585-014-9647-4

154. Patel D, Ellis R, Howard B, Boufraqech M, Gara SK, Zhang L, et al. Analysis of IGF and IGFBP as prognostic serum biomarkers for adrenocortical carcinoma. Ann Surg Oncol (2014) 21(11):3541-7. doi:10.1245/s10434-014-3768-5

155. McCaffery I, Tudor Y, Deng H, Tang R, Suzuki S, Badola S, et al. Putative predictive biomarkers of survival in patients with metastatic pancreatic adenocarcinoma treated with gemcitabine and ganitumab, an IGF1R inhibitor. Clin Cancer Res (2013) 19(15):4282-9. doi:10.1158/1078-0432.CCR-12-1840

156. Roddam AW, Allen NE, Appleby P, Key TJ, Ferrucci L, Carter HB, et al. Insulin-like growth factors, their binding proteins, and prostate cancer risk: analysis of individual patient data from 12 prospective studies. Ann Intern Med (2008) 149(7):W83-8. doi:10.7326/0003-4819-149-7-200810070-00006

157. Tworoger SS, Lee IM, Buring JE, Pollak MN, Hankinson SE. Insulin-like growth factors and ovarian cancer risk: a nested case-control study in three cohorts. Cancer Epidemiol Biomarkers Prev (2007) 16(8):1691-5. doi:10.1158/ 1055-9965.EPI-07-0319

158. Lee EJ, Mircean C, Shmulevich I, Wang H, Liu J, Niemistö A, et al. Insulin-like growth factor binding protein 2 promotes ovarian cancer cell invasion. $\mathrm{Mol}$ Cancer (2005) 4(1):7. doi:10.1186/1476-4598-4-7

159. Baron-Hay S, Boyle F, Ferrier A, Scott C. Elevated serum insulin-like growth factor binding protein-2 as a prognostic marker in patients with ovarian cancer. Clin Cancer Res (2004) 10(5):1796-806. doi:10.1158/1078-0432. CCR-0672-2
160. Chakrabarty S, Kondratick L. Insulin-like growth factor binding protein2 stimulates proliferation and activates multiple cascades of the mitogenactivated protein kinase pathways in NIH-OVCAR3 human epithelial ovarian cancer cells. Cancer Biol Ther (2006) 5(2):189-97. doi:10.4161/cbt.5.2.2333

161. Rinaldi S, Cleveland R, Norat T, Biessy C, Rohrmann S, Linseisen J, et al. Serum levels of IGF-I, IGFBP-3 and colorectal cancer risk: results from the EPIC cohort, plus a meta-analysis of prospective studies. Int J Cancer (2010) 126(7):1702-15. doi:10.1002/ijc.24927

162. Baglietto L, English DR, Hopper JL, Morris HA, Tilley WD, Giles GG. Circulating insulin-like growth factor-I and binding protein-3 and the risk of breast cancer. Cancer Epidemiol Biomarkers Prev (2007) 16(4):763-8. doi:10.1158/ 1055-9965.EPI-06-0960

163. Rollison DE, Giuliano AR, Risendal BC, Sweeney C, Boulware D, Laronga C, et al. Serum insulin-like growth factor (IGF)-1 and IGF binding protein-3 in relation to breast cancer among Hispanic and white, non-Hispanic women in the US Southwest. Breast Cancer Res Treat (2010) 121(3):661-9. doi:10.1007/ s10549-009-0609-5

164. Gunter MJ, Hoover DR, Yu H, Wassertheil-Smoller S, Rohan TE, Manson $\mathrm{JE}$, et al. Insulin, insulin-like growth factor-I, and risk of breast cancer in postmenopausal women. J Natl Cancer Inst (2009) 101(1):48-60. doi:10.1093/ jnci/djp159

165. Vatten LJ, Holly JM, Gunnell D, Tretli S. Nested case-control study of the association of circulating levels of serum insulin-like growth factor I and insulin-like growth factor binding protein 3 with breast cancer in young women in Norway. Cancer Epidemiol Biomarkers Prev (2008) 17(8):2097-100. doi:10.1158/1055-9965.EPI-08-0212

166. Hartog H, Boezen HM, de Jong MM, Schaapveld M, Wesseling J, van der Graaf WT. Prognostic value of insulin-like growth factor 1 and insulin-like growth factor binding protein 3 blood levels in breast cancer. Breast (2013) 22(6):1155-60. doi:10.1016/j.breast.2013.07.038

167. Duggan C, Wang CY, Neuhouser ML, Xiao L, Smith AW, Reding KW, et al. Associations of insulin-like growth factor and insulin-like growth factor binding protein-3 with mortality in women with breast cancer. Int J Cancer (2013) 132(5):1191-200. doi:10.1002/ijc.27753

168. Sheen-Chen SM, Zhang H, Huang CC, Tang RP. Insulin-like growth factorbinding protein-3 in breast cancer: analysis with tissue microarray. Anticancer Res (2009) 29(4):1131-5.

169. Ren Z, Shin A, Cai Q, Shu XO, Gao YT, Zheng W. IGFBP3 mRNA expression in benign and malignant breast tumors. Breast Cancer Res (2007) 9(1):R2 doi:10.1186/bcr1634

170. Holdaway IM, Mason BH, Lethaby AE, Singh V, Harvey VJ, Thompson PI, et al. Serum insulin-like growth factor-I and insulin-like growth factor binding protein-3 following chemotherapy for advanced breast cancer. ANZ J Surg (2003) 73(11):905-8. doi:10.1046/j.1445-2197.2003.02817.x

171. Johansson M, McKay JD, Rinaldi S, Wiklund F, Adami HO, Grönberg H, et al. Genetic and plasma variation of insulin-like growth factor binding proteins in relation to prostate cancer incidence and survival. Prostate (2009) 69(12):1281-91. doi:10.1002/pros.20972

172. Nimptsch K, Platz EA, Pollak MN, Kenfield SA, Stampfer MJ, Willett WC, et al. Plasma insulin-like growth factor 1 is positively associated with low-grade prostate cancer in the health professionals follow-up study 1993-2004. Int J Cancer (2011) 128(3):660-7. doi:10.1002/ijc.25381

173. Platz EA, Pollak MN, Leitzmann MF, Stampfer MJ, Willett WC, Giovannucci E. Plasma insulin-like growth factor- 1 and binding protein- 3 and subsequent risk of prostate cancer in the PSA era. Cancer Causes Control (2005) 16(3):255-62. doi:10.1007/s10552-004-3484-8

174. Seligson DB, Yu H, Tze S, Said J, Pantuck AJ, Cohen P, et al. IGFBP-3 nuclear localization predicts human prostate cancer recurrence. Horm Cancer (2013) 4(1):12-23. doi:10.1007/s12672-012-0124-8

175. Allen NE, Key TJ, Appleby PN, Travis RC, Roddam AW, Rinaldi S, et al. Serum insulin-like growth factor (IGF)-I and IGF-binding protein-3 concentrations and prostate cancer risk: results from the European prospective investigation into cancer and nutrition. Cancer Epidemiol Biomarkers Prev (2007) 16(6):1121-7. doi:10.1158/1055-9965.EPI-06-1062

176. Tsilidis KK, Travis RC, Appleby PN, Allen NE, Lindström S, Albanes D, et al. Insulin-like growth factor pathway genes and blood concentrations, dietary protein and risk of prostate cancer in the NCI breast and prostate cancer cohort consortium (BPC3). Int J Cancer (2013) 133(2):495-504. doi:10.1002/ijc.28042 
177. Chen B, Liu S, Xu W, Wang X, Zhao W, Wu J. IGF-I and IGFBP-3 and the risk of lung cancer: a meta-analysis based on nested case-control studies. J Exp Clin Cancer Res (2009) 28:89. doi:10.1186/1756-9966-28-89

178. Vollebergh MA, Kappers I, Klomp HM, Buning-Kager JC, Korse CM, Hauptmann $\mathrm{M}$, et al. Ligands of epidermal growth factor receptor and the insulin-like growth factor family as serum biomarkers for response to epidermal growth factor receptor inhibitors in patients with advanced non-small cell lung cancer. J Thorac Oncol (2010) 5(12):1939-48. doi:10.1097/JTO.0b013e3181f77a39

179. Han JY, Choi BG, Choi JY, Lee SY, Ju SY. The prognostic significance of pretreatment plasma levels of insulin-like growth factor (IGF)-1, IGF-2, and IGF binding protein-3 in patients with advanced non-small cell lung cancer. Lung Cancer (2006) 54(2):227-34. doi:10.1016/j.lungcan.2006.07.014

180. Chang YS, Kong G, Sun S, Liu D, El-Naggar AK, Khuri FR, et al. Clinical significance of insulin-like growth factor-binding protein-3 expression in stage I non-small cell lung cancer. Clin Cancer Res (2002) 8(12):3796-802.

181. Gunter MJ, Hoover DR, Yu H, Wassertheil-Smoller S, Manson JE, Li J, et al. A prospective evaluation of insulin and insulin-like growth factor-I as risk factors for endometrial cancer. Cancer Epidemiol Biomarkers Prev (2008) 17(4):921-9. doi:10.1158/1055-9965.EPI-07-2686

182. Peeters PH, Lukanova A, Allen N, Berrino F, Key T, Dossus L, et al. Serum IGFI, its major binding protein (IGFBP-3) and epithelial ovarian cancer risk: the European prospective investigation into cancer and nutrition (EPIC). Endocr Relat Cancer (2007) 14(1):81-90. doi:10.1677/erc.1.01264

183. Wolpin BM, Michaud DS, Giovannucci EL, Schernhammer ES, Stampfer MJ, Manson JE, et al. Circulating insulin-like growth factor axis and the risk of pancreatic cancer in four prospective cohorts. Br J Cancer (2007) 97(1):98-104. doi: $10.1038 /$ sj.bjc. 6603826

184. Rohrmann S, Grote VA, Becker S, Rinaldi S, Tjønneland A, Roswall N, et al. Concentrations of IGF-I and IGFBP-3 and pancreatic cancer risk in the european prospective investigation into cancer and nutrition. Br J Cancer (2012) 106(5):1004-10. doi:10.1038/bjc.2012.19

185. Pham TM, Fujino Y, Kikuchi S, Tamakoshi A, Yatsuya H, Kubo T, et al. A nested case-control study of stomach cancer incidence and serum superoxide dismutase activity in the Japan collaborative cohort study in Japan. Cancer Detect Prev (2007) 31(6):431-5. doi:10.1016/j.cdp.2007.10.012

186. Major JM, Pollak MN, Snyder K, Virtamo J, Albanes D. Insulin-like growth factors and risk of kidney cancer in men. Br J Cancer (2010) 103(1):132-5. doi:10.1038/sj.bjc.6605722

187. Tas F, Karabulut S, Serilmez M, Ciftci R, Duranyildiz D. Clinical significance of serum insulin-like growth factor-1 (IGF-1) and insulinlike growth factor binding protein-3 (IGFBP-3) in patients with epithelial ovarian cancer. Tumour Biol (2014) 35(4):3125-32. doi:10.1007/s13277-013-1405-8

188. Torng PL, Lee YC, Huang CY, Ye JH, Lin YS, Chu YW, et al. Insulin-like growth factor binding protein-3 (IGFBP-3) acts as an invasion-metastasis suppressor in ovarian endometrioid carcinoma. Oncogene (2008) 27(15):2137-47. doi:10. 1038/sj.onc. 1210864

189. Papadimitrakopoulou VA, Brown EN, Liu DD, El-Naggar AK, Jack Lee J, Hong WK, et al. The prognostic role of loss of insulin-like growth factor-binding protein-3 expression in head and neck carcinogenesis. Cancer Lett (2006) 239(1):136-43. doi:10.1016/j.canlet.2005.08.009

190. Xue M, Fang Y, Sun G, Zhuo W, Zhong J, Qian C, et al. IGFBP3, a transcriptional target of homeobox D10, is correlated with the prognosis of gastric cancer. PLoS One (2013) 8(12):e81423. doi:10.1371/journal.pone.0081423

191. Zhao L, He LR, Zhang R, Cai MY, Liao YJ, Qian D, et al. Low expression of IGFBP-3 predicts poor prognosis in patients with esophageal squamous cell carcinoma. Med Oncol (2012) 29(4):2669-76. doi:10.1007/s12032-011-0133-4

192. Aishima S, Basaki Y, Oda Y, Kuroda Y, Nishihara Y, Taguchi K, et al. High expression of insulin-like growth factor binding protein-3 is correlated with lower portal invasion and better prognosis in human hepatocellular carcinoma. Cancer Sci (2006) 97(11):1182-90. doi:10.1111/j.1349-7006.2006. 00322.x

193. Santosh V, Arivazhagan A, Sreekanthreddy P, Srinivasan H, Thota B, Srividya $\mathrm{MR}$, et al. Grade-specific expression of insulin-like growth factor-binding proteins-2, -3 , and -5 in astrocytomas: IGFBP-3 emerges as a strong predictor of survival in patients with newly diagnosed glioblastoma. Cancer Epidemiol Biomarkers Prev (2010) 19(6):1399-408. doi:10.1158/1055-9965. EPI-09-1213

194. Naing A, Kurzrock R, Burger A, Gupta S, Lei X, Busaidy N, et al. Phase I trial of cixutumumab combined with temsirolimus in patients with advanced cancer. Clin Cancer Res (2011) 17(18):6052-60. doi:10.1158/1078-0432. CCR-10-2979

195. Mita K, Zhang Z, Ando Y, Toyama T, Hamaguchi M, Kobayashi S, et al. Prognostic significance of insulin-like growth factor binding protein (IGFBP)-4 and IGFBP-5 expression in breast cancer. Jpn J Clin Oncol (2007) 37(8):575-82. doi:10.1093/jjco/hym066

196. Mosig RA, Lobl M, Senturk E, Shah H, Cohen S, Chudin E, et al. IGFBP-4 tumor and serum levels are increased across all stages of epithelial ovarian cancer. J Ovarian Res (2012) 5(1):3. doi:10.1186/1757-2215-5-3

197. Becker MA, Hou X, Harrington SC, Weroha SJ, Gonzalez SE, Jacob KA, et al. IGFBP ratio confers resistance to IGF targeting and correlates with increased invasion and poor outcome in breast tumors. Clin Cancer Res (2012) 18(6):1808-17. doi:10.1158/1078-0432.CCR-11-1806

198. Li X, Cao X, Li X, Zhang W, Feng Y. Expression level of insulin-like growth factor binding protein $5 \mathrm{mRNA}$ is a prognostic factor for breast cancer. Cancer Sci (2007) 98(10):1592-6. doi:10.1111/j.1349-7006.2007.00565.x

199. Ahn BY, Elwi AN, Lee B, Trinh DL, Klimowicz AC, Yau A, et al. Genetic screen identifies insulin-like growth factor binding protein 5 as a modulator of tamoxifen resistance in breast cancer. Cancer Res (2010) 70(8):3013-9. doi:10.1158/0008-5472.CAN-09-3108

200. Haluska P, Bernath M, Ballman K. Randomized phase II trial of capecitabine and lapatinib with or without cixutumumab in patients with HER2+ breast cancer previously treated with trastuzumab and an anthracycline and/or a taxane: NCCTG N0733 (Alliance). J Clin Oncol (2014) 32(5s):sul;abstr632.

201. Liang PI, Wang YH, Wu TF, Wu WR, Liao AC, Shen KH, et al. IGFBP-5 overexpression as a poor prognostic factor in patients with urothelial carcinomas of upper urinary tracts and urinary bladder. J Clin Pathol (2013) 66(7):573-82. doi:10.1136/jclinpath-2012-201278

202. Pavlicek A, Lira ME, Lee NV, Ching KA, Ye J, Cao J, et al. Molecular predictors of sensitivity to the insulin-like growth factor 1 receptor inhibitor Figitumumab (CP-751,871). Mol Cancer Ther (2013) 12(12):2929-39. doi:10. 1158/1535-7163.MCT-13-0442-T

203. Massie C, Mills IG. The developing role of receptors and adaptors. Nat Rev Cancer (2006) 6(5):403-9. doi:10.1038/nrc1882

204. Lin SY, Makino K, Xia W, Matin A, Wen Y, Kwong KY, et al. Nuclear localization of EGF receptor and its potential new role as a transcription factor. Nat Cell Biol (2001) 3(9):802-8. doi:10.1038/ncb0901-802

205. Wang YN, Yamaguchi H, Hsu JM, Hung MC. Nuclear trafficking of the epidermal growth factor receptor family membrane proteins. Oncogene (2010) 29(28):3997-4006. doi:10.1038/onc.2010.157

206. Dittmann K, Mayer C, Fehrenbacher B, Schaller M, Raju U, Milas L, et al. Radiation-induced epidermal growth factor receptor nuclear import is linked to activation of DNA-dependent protein kinase. J Biol Chem (2005) 280(35):31182-9. doi:10.1074/jbc.M506591200

207. Brand TM, Iida M, Luthar N, Starr MM, Huppert EJ, Wheeler DL. Nuclear EGFR as a molecular target in cancer. Radiother Oncol (2013) 108(3):370-7. doi:10.1016/j.radonc.2013.06.010

208. Aleksic T, Chitnis MM, Perestenko OV, Gao S, Thomas PH, Turner GD, et al. Type 1 insulin-like growth factor receptor translocates to the nucleus of human tumor cells. Cancer Res (2010) 70(16):6412-9. doi:10.1158/0008-5472. CAN-10-0052

209. Deng H, Lin Y, Badin M, Vasilcanu D, Strömberg T, Jernberg-Wiklund H, et al. Over-accumulation of nuclear IGF-1 receptor in tumor cells requires elevated expression of the receptor and the SUMO-conjugating enzyme Ubc9. Biochem Biophys Res Commun (2011) 404(2):667-71. doi:10.1016/j.bbrc.2010.12.038

210. Warsito D, Sjöström S, Andersson S, Larsson O, Sehat B. Nuclear IGF1R is a transcriptional co-activator of LEF1/TCF. EMBO Rep (2012) 13(3):244-50. doi:10.1038/embor.2011.251

211. Salani B, Passalacqua M, Maffioli S, Briatore L, Hamoudane M, Contini P, et al. IGF-IR internalizes with caveolin-1 and PTRF/Cavin in HaCat cells. PLoS One (2010) 5(11):e14157. doi:10.1371/journal.pone.0014157

212. Huo H, Guo X, Hong S, Jiang M, Liu X, Liao K. Lipid rafts/caveolae are essential for insulin-like growth factor-1 receptor signaling during 3T3-L1 preadipocyte differentiation induction. J Biol Chem (2003) 278(13):11561-9. doi:10.1074/jbc.M211785200

213. Romanelli RJ, LeBeau AP, Fulmer CG, Lazzarino DA, Hochberg A, Wood TL. Insulin-like growth factor type-I receptor internalization and recycling mediate the sustained phosphorylation of Akt. J Biol Chem (2007) 282(31):22513-24. doi:10.1074/jbc.M704309200 
214. Sehat B, Tofigh A, Lin Y, Trocmé E, Liljedahl U, Lagergren J, et al. SUMOylation mediates the nuclear translocation and signaling of the IGF-1 receptor. Sci Signal (2010) 3(108):ra10. doi:10.1126/scisignal.2000628

215. Hoelz A, Debler EW, Blobel G. The structure of the nuclear pore complex. Annu Rev Biochem (2011) 80:613-43. doi:10.1146/annurev-biochem060109-151030

216. Wu YC, Zhu M, Robertson DM. Novel nuclear localization and potential function of insulin-like growth factor-1 receptor/insulin receptor hybrid in corneal epithelial cells. PLoS One (2012) 7(8):e42483. doi:10.1371/journal. pone. 0042483

217. Bodzin AS, Wei Z, Hurtt R, Gu T, Doria C. Gefitinib resistance in HCC mahlavu cells: upregulation of CD133 expression, activation of IGF-1R signaling pathway, and enhancement of IGF-1R nuclear translocation. J Cell Physiol (2012) 227(7):2947-52. doi:10.1002/jcp.23041

218. Asmane I, Watkin E, Alberti L, Duc A, Marec-Berard P, Ray-Coquard I, et al. Insulin-like growth factor type 1 receptor (IGF-1R) exclusive nuclear staining: a predictive biomarker for IGF-1R monoclonal antibody $(\mathrm{Ab})$ therapy in sarcomas. Eur J Cancer (2012) 48(16):3027-35. doi:10.1016/j.ejca.2012. 05.009

219. Potratz JC, Saunders DN, Wai DH, Ng TL, McKinney SE, Carboni JM, et al. Synthetic lethality screens reveal RPS6 and MST1R as modifiers of insulin-like growth factor-1 receptor inhibitor activity in childhood sarcomas. Cancer Res (2010) 70(21):8770-81. doi:10.1158/0008-5472.CAN-10-1093

220. Gao S, Bajrami I, Verrill C, Kigozi A, Ouaret D, Aleksic T, et al. Dsh homolog DVL3 mediates resistance to IGFIR inhibition by regulating IGFRAS signaling. Cancer Res (2014) 74(20):5866-77. doi:10.1158/0008-5472. CAN-14-0806

221. Lodhia KA, Gao S, Aleksic T, Esashi F, Macaulay VM. Suppression of homologous recombination sensitizes human tumor cells to IGF-1R inhibition. Int $J$ Cancer (2015) 136(12):2961-66. doi:10.1002/ijc.29327

222. Kang HJ, Yi YW, Kim HJ, Hong YB, Seong YS, Bae I. BRCA1 negatively regulates IGF-1 expression through an estrogen-responsive element-like site. Cell Death Dis (2012) 3:e336. doi:10.1038/cddis.2012.78

223. Neuhausen SL, Brummel S, Ding YC, Singer CF, Pfeiler G, Lynch HT, et al. Genetic variation in insulin-like growth factor signaling genes and breast cancer risk among BRCA1 and BRCA2 carriers. Breast Cancer Res (2009) 11(5):R76. doi:10.1186/bcr2414

224. Creighton CJ, Casa A, Lazard Z, Huang S, Tsimelzon A, Hilsenbeck SG, et al. Insulin-like growth factor-I activates gene transcription programs strongly associated with poor breast cancer prognosis. J Clin Oncol (2008) 26(25):4078-85. doi:10.1200/JCO.2007.13.4429
225. Creighton CJ, Fu X, Hennessy BT, Casa AJ, Zhang Y, Gonzalez-Angulo AM, et al. Proteomic and transcriptomic profiling reveals a link between the PI3K pathway and lower estrogen-receptor (ER) levels and activity in ER+ breast cancer. Breast Cancer Res (2010) 12(3):R40. doi:10.1186/bcr2594

226. Friedbichler K, Hofmann MH, Kroez M, Ostermann E, Lamche HR, Koessl C, et al. Pharmacodynamic and antineoplastic activity of BI 836845, a fully human IGF ligand-neutralizing antibody, and mechanistic rationale for combination with rapamycin. Mol Cancer Ther (2014) 13(2):399-409. doi:10.1158/ 1535-7163.MCT-13-0598

227. Gao J, Chesebrough JW, Cartlidge SA, Ricketts SA, Incognito L, VeldmanJones $\mathrm{M}$, et al. Dual IGF-I/II-neutralizing antibody MEDI-573 potently inhibits IGF signaling and tumor growth. Cancer Res (2011) 71(3):1029-40. doi:10.1158/0008-5472.CAN-10-2274

228. Haluska P, Menefee M, Plimack ER, Rosenberg J, Northfelt D, LaVallee T, et al. Phase I dose-escalation study of MEDI-573, a bispecific, antiligand monoclonal antibody against IGFI and IGFII, in patients with advanced solid tumors. Clin Cancer Res (2014) 20(18):4747-57. doi:10.1158/1078-0432. CCR-14-0114

229. Davison Z, de Blacquière GE, Westley BR, May FE. Insulin-like growth factordependent proliferation and survival of triple-negative breast cancer cells: implications for therapy. Neoplasia (2011) 13(6):504-15. doi:10.1593/neo. 101590

230. Hartog H, Horlings HM, van der Vegt B, Kreike B, Ajouaou A, van de Vijver $M J$, et al. Divergent effects of insulin-like growth factor-1 receptor expression on prognosis of estrogen receptor positive versus triple negative invasive ductal breast carcinoma. Breast Cancer Res Treat (2011) 129(3):725-36. doi:10.1007/ s10549-010-1256-6

231. Zinn RL, Gardner EE, Marchionni L, Murphy SC, Dobromilskaya I, Hann CL, et al. ERK phosphorylation is predictive of resistance to IGF-1R inhibition in small cell lung cancer. Mol Cancer Ther (2013) 12(6):1131-9. doi:10.1158/ 1535-7163.MCT-12-0618

Conflict of Interest Statement: The authors declare that the research was conducted in the absence of any commercial or financial relationships that could be construed as a potential conflict of interest.

Copyright (-) 2015 Lodhia, Tienchaiananda and Haluska. This is an open-access article distributed under the terms of the Creative Commons Attribution License (CC BY). The use, distribution or reproduction in other forums is permitted, provided the original author(s) or licensor are credited and that the original publication in this journal is cited, in accordance with accepted academic practice. No use, distribution or reproduction is permitted which does not comply with these terms. 